耳鼻臨床＼cjkstart補56 : 1 30, 1992

\title{
耳鳴ラウドネスの聴覚心理学的測定法
}

\author{
原田昌彦
}

\section{Psychoacoustical Measurement of Tinnitus Loudness}

\author{
Masahiko Harada \\ (Kinki University)
}

A computerized method for the continuous measurement of tinnitus loudness has been developed. To evaluate this method the following experiments were done.

[Experiment 1]

Pseudo tinnitus was induced in the right ear, in 20 individuals with normal hearing. The loudness of tinnitus was determined by a newly developed constant method and the loudness balance method. The latter is a standard method used for tinnitus examination established in 1984 by the Audiological Society of Japan. The design is based on the Fowler method (standard method). The values obtained with the constant method were significantly higher than those obtained with the standard method.

[Experiment 2]

Tinnitus loudness was measured in 12 ears of 12 patients with tinnitus by 2 examiners each using both the constant method and the standard method. With the standard method there were differences of about $5 \mathrm{~dB}$ in the value of tinnitus loudness between the measurements obtained by the two examiners. However, with the constant method those differences were less than $5 \mathrm{~dB}$.

[Experiment 3]

Simulation of the loudness balance examination was performed in a computerized model that followed Thurstone's law of comparative judgment using a determined value of tinnitus loudness. No large differences were found between the constant and standard methods regardless of the stimulation order. But in tinnitus loudness measured in tinnitus patients, significant differences were found between the two methods. From these results, the series effect during the loudness balance examination is expected to be large.

[Experiment 4]

Tinnitus loudness in the affected ear and in the contralateral ear was measured in 18 patients with unilateral tinnitus, and the effective loudness (absolute magnitude of tinnitus loudness) was determined after correction for the recruitment phenomenon using $\mathrm{Ma}$ tsuhira's loudness function. The correlation coefficient between the evaluation of the affected ear and that of the contralateral ear was 0.83 with the constant method and 0.30 with the standard method. Therefore, to determine the effective loudness the constant method is more practical.

Key words: tinnitus loudness, constant method, psychoacoustical measurement, loudness balance test, computerized measurement 
目次

I 、はじめに

II. 実 験

《実験 $1 》$ 擬似耳鳴によるラウドネス測定 実験

一標準耳鳴検査法1984 と恒常法との比較一

《実験 2 》耳鳴ラウドネス値の検者による違 い(恒常法と標準法の比較)につい ての実験

一 2 人の検者による耳鳴ラウドネス実測值 の違い一

《実験 $3 》$ 検査法の違いによる実測値の差の 生じる理由の解明

ーラウドネス・バランス検査のシミュレー ション実験による実証一

\section{I ．はじめに}

耳鳴検査は, Fowler ${ }^{1)}$ が対側耳でブラケット 法によるピッチ・マッチ検査とラウドネス・バ ランス検査を行ったのが最初とされている．現 在わが国では，耳鳴の大きさの測定には一般的 に標準耳鳴検査法19842) のラウドネス・バラン ス検査（標準法）が用いられている. 基本的に は Fowler の方法と大きく変わっていない，標 準法では $5 \mathrm{~dB}$ ステップの極限法で行らことに なっている．実際には耳鳴のラウドネスは，10 $\mathrm{dB}$ 以下3)のことが多く $5 \mathrm{~dB}$ ステップの測定で は精度の面からみて量的な評価は 3 段階であり， 治療効果の判定やラウドネスの比較などに用い るには問題がある。しかし極限法に拈いて 2 $\mathrm{dB}$ や $1 \mathrm{~dB}$ ステップの測定は系列効果4)(期待 誤差, 慣れの誤差, 刺激誤差など) や判断誤差 により測定ごとに值が異なり一定の実測值を得 ることが困難となる。

実際の臨床では極限法のよらな刺激発見法が
《実験 4 》耳鳴ラウドネス值の評価に拈ける 問題点汇関する実験

一感音性難聴耳の補充現象を中心に考察—

\section{III. 全編の考察}

1. 恒常法の方法論

[比較判断の法則]

[恒常法の検查手続き]

[検査法の効率化]

2. 耳鳴検査法の現状と将来への展望

N. おわりに

謝辞

参考文献

測定効率の良さの理由から用いられてきた。耳 鳴のよらなラウドネスの小さなものに対しては, 聴力検査よりも細かいステップの測定を必要と するが，刺激発見法としては， $5 \mathrm{~dB}$ ステップ の精度で測定するのが限度である.

また標準法による耳鳴ラウドネスの感覚レベ ル（以下 SL)の測定に拈いて, 最小可聴閾値 測定の場合とは異なった刺激の呈示法と判断法 が用いられるため SL 值が負の值になるという 奇妙なデータの報告すらみられる5). 負の值を どら解釈するかは議論の分かれるところである が，矛盾を感じるのも事実である.

そこで精度的に最も洗練された聴覚心理学的 測定法である恒常法により，耳鳴ラウドネス測 定と SL 值を求めるための最小可聴閾值測定を 行ら必要性があると考光, その測定法沶よび測 定精度やその問題点につき様々な角度から検討 した。 


\section{II. 実 験}

閾値または弁別間 $\mu$ が心理連続体上に存在 する場合刺激 $S_{i}$ が $\mu$ を越えている（識別また は弁別される）確率 $p$ は精神測定関数

$$
p=\frac{1}{\sqrt{2 \pi} \sigma_{i}} \int_{-\infty}^{S_{i}} \exp \left\{-\frac{1}{2}\left(\frac{S-\mu}{\sigma_{i}}\right)^{2}\right\} d S
$$

で表される. 聴覚検査は心理量 $\mu$ （精神測定関 数の平均值で実測不可能）を恒常法に限らず聴 覚心理学的方法によって推定することである. その心理量 $\mu$ の恒常法による推定を $\hat{\mu}(ミ ュ ー$ ・八ット）で表し，極限法または上昇法による 推定を $\tilde{\mu}$ (ミュー・ティルド) とした. 以下本 論文中の精神測定関数のパラメータや標準法に よるパラメータを表 1 に示す。実験に使用した 恒常法の方法論については第而章にて後述する.

\section{《実験 1 》}

擬似耳鳴によるラウドネス測定実験

一標準耳鳴検查法1984 と恒常法との比較一

1) 目 的

恒常法による耳鳴ラウドネス測定（以下恒常 法）と標準耳鳴検査法1984のラウドネスバラン ス法（以下標準法）との測定精度，測定効率な どの差をみることを目的とした。

耳鳴ラウドネス測定の精度打よび耳鳴の強さ
と実測值との関係を調べるのには，耳鳴の大き さを一定に保ち，場合により任意に変化させる ことも必要であるが実際の耳鳴ではそのような 操作は不可能であるので擬似耳鳴を使用し実験 を行った。

\section{2) 方 法}

[対 象]

24歳から43歳の耳鳴のない聴力正常の男子 20 名の右耳で検査した。

[実験機器〕

パーソナルコンピュータ, NEC 社製 PC-9801 VX に, FM 音源ボード PC-9801-26K を内蔵し 刺激を発生させる。それをオージオメータ，リ オン社製 AA-61BN を通して被検者に刺激を与 える. 検査手続きや精神測定関数の計算プログ ラム言語は，BASIC を用い，データをそのま ま統計処理できるようにするファイル変換プロ グラムも作成した.

[実験方法]

図 1 のように骨導受話器を前額部に圧着し, 左耳は気導受話器を通して $1 \mathrm{kHz}$ のバンドノ イズでマスキングした。まず $2 / \mathrm{sec}$, duty cycle $50 \%$ の断続音の $1 \mathrm{kHz}$ 純音で，上昇法により 骨導聴力を測定し，その閾值上 $10,12,14 \mathrm{~dB}$

表 1 本論文で用いる精神測定関数のパラメータの記号

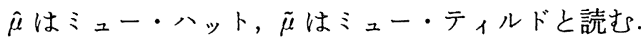

\begin{tabular}{|c|c|}
\hline$\mu$ & 反応の母集団より求めた精神測定関数の平均值（絶対闆, 等価値) \\
\hline$\sigma$ & 上記の関数の標準偏差 \\
\hline$\hat{\mu}$ & $\begin{array}{l}\text { 反応の母集団より任意抽出した標本より推測した精神測定 } \\
\text { 関数の平均値つまり恒常法による実測値 }\end{array}$ \\
\hline$\hat{\sigma}$ & 上記の関数の標準偏差 \\
\hline$\tilde{\mu}$ & $\begin{array}{l}\text { 反応の母集団より任意抽出でない標本からの } \mu \text { の推定値つ } \\
\text { まり刺激発見法 (上昇法, 極限法) で求めた実測値 }\end{array}$ \\
\hline$\mu_{0}$ & 最小可聴閾値 （母平均で測定不可能） \\
\hline$\hat{\mu}_{0}$ & 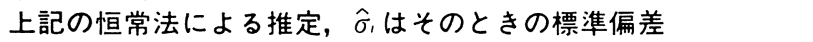 \\
\hline$\widetilde{\mu}_{0}$ & 上記の上昇法による推定 \\
\hline$\mu_{T}$ & 耳鳴ラウドネスのHL値（測定不可能）SL値は $\mu_{0}-\mu_{T}$ \\
\hline$\hat{\mu}_{T}$ & $\begin{array}{l}\text { 上記の恒常法による推定， } \hat{\sigma}_{T} \text { はそのときの標準偏差, } \\
\text { SL値は } \hat{\mu}_{T}-\hat{\mu}_{0}\end{array}$ \\
\hline$\widehat{\mu}_{T}$ & 上記の標準耳鳴検査法による推定，SL値は $\widetilde{\mu}_{T}$ 一 $\widetilde{\mu}_{0}$ \\
\hline
\end{tabular}


の 3 種類の $1 \mathrm{kHz}$ 純音を擬似耳鳴として与え た。擬似耳鳴刺激に対し，できるだけうなりな どの干渉を避けるために検査刺激を $1.2 \mathrm{kHz}$ の純音とし，恒常法と標準法で擬似耳鳴刺激の ラウドネスを検査刺激と同時比較で求めた。検 査刺激の呈示法を図 2 に示す。

標準法の場合, 最小可聴閾值は通常の純音聴 力検査法に従った。 また擬似耳鳴の順応 (adaptation) $)^{67)}$ を避けるために, 検査の刺激音 $1 \mathrm{sec}$ にして擬似耳鳴約 $3 \mathrm{sec}$ とし比較が終わる度に 擬似耳鳴は約 $2 \mathrm{sec}$ 止めた. 検査音を $1 \mathrm{sec} に$ したのは, $800 \mathrm{msec}$ 以下の単音は持続時間が 短い程，ラウドネスが小さくなる可能性がある からである8). 同時比較にしたのは, 実際の耳 鳴のバランス検査の場合がそうであることと, 時間順序誤差を考慮しないで斉むようにである． 標準法のラウドネスバランスは, $1 \mathrm{~dB}$ ステッ プの上昇法で行った. 恒常法の場合, 刺激系列 は $1 \mathrm{~dB}$ 間隔の 10 音とし標準法の実測值を参考 にして決定した。検查刺激は刺激系列の 1 水準 あたり10回ランダムの順序で呈示した。つまり 検查刺激は, 計 100 回呈示することになる. 実 測值は, 標準法も恒常法もSL 值（恒常法の場 合 $\left.\hat{\mu}_{T}-\hat{\mu}_{0}\right)$ で表した.

3 ) 結 果

[擬似耳鳴強度と実測值]

図 3 は擬似耳鳴刺激強度と耳鳴ラウドネス実 測值の関係を表し，同一症例を実線で結んであ る. 恒常法の場合は, 擬似耳鳴強度が増すにつ れて実測值も増加した症例が多いが，標準法の 場合, 擬似耳鳴強度と実測值の間の相関が汪と
んどなく擬似耳鳴強度が増加しても逆に実測值 が減少している場合も多数みられる。またそれ ぞれの関係の 1 次回帰をとると, 恒常法の場合 $y=2.67+1.20 x$ となり, 標準法の場合は $y=$ $3.1+0.38 x$ といら関係になる。これを見ると 恒常法の方が精度が高いといらことは明らかで ある。また，恒常法による実測值の方が全体的 に高値を示した。

\section{〔測定誤差〕}

図 3 で示した関係において, 擬似耳鳴強度が $2 \mathrm{~dB}$ ずつ増加するにつれてその実測值が $2 \mathrm{~dB}$ ずつ増加する場合は誤差が 0 と考光る。つまり 誤差がなければ擬似耳鳴が $10,12,14 \mathrm{dBSL}$ と 変化するにつれ耳鳴ラウドネス値は, $\mu_{T}, \mu_{T}+$ 2， $\mu_{T}+4$ となるはずである. それぞれの実測 值を $\hat{\mu}_{T 10}, \hat{\mu}_{T 12}, \hat{\mu}_{T 14}$ とし擬似耳鳴強度が 12,14 $\mathrm{dBSL}$ のときの誤差（心理的変動）を

$$
\begin{aligned}
\varepsilon_{12}, \varepsilon_{14} \text { とすると } \varepsilon_{12} & =\left|\hat{\mu}_{T 12}-\left(\hat{\mu}_{T 10}+2\right)\right| \\
\varepsilon_{14} & =\left|\hat{\mu}_{T 14}-\left(\hat{\mu}_{T 14}+4\right)\right|
\end{aligned}
$$

となる. $\hat{\mu}_{T 10}$ も誤差を含んでいるはずであるが， 変動をみるためにここでは基準值とした．標準 法の場合は上記の式の $\hat{\mu} の$ 代わりに $\tilde{\mu}$ が入る.

恒常法による測定と標準法による測定の場合 の誤差のヒストグラムを図 4 に示す. $\mathrm{t}$ 検定で

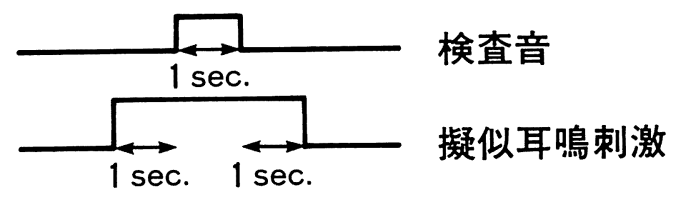

図 2 凝似耳鳴之検査音の呈示法

被検者の応答 1 秒後に凝似耳鳴が呈示される.

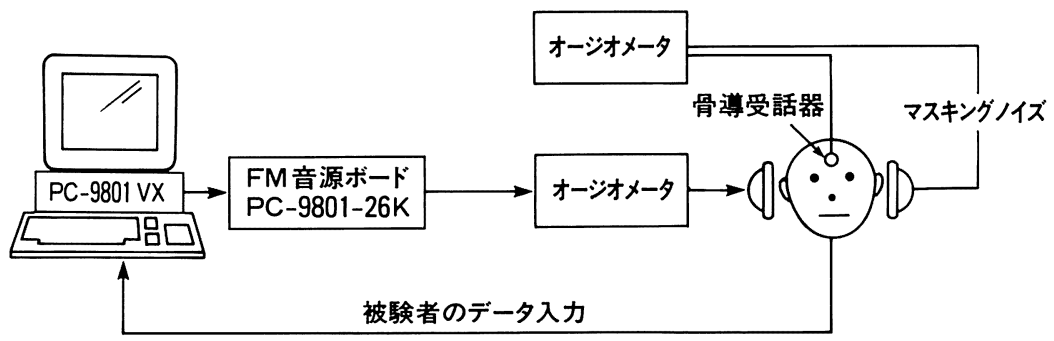

図 1 凝似耳鳴実験のための実験装置のブロック・ダイアグラム 
恒常法の誤差が有意に小さいという結果になっ た $(\mathrm{p}<0.01)$.

〔精神測定関数の標準偏差〕

精神測定関数の標準偏差は, 比較判断の法則 に执いて心理的变動による標準誤差の指標とし て位置づけられている9 . 標準偏差と測定誤差 との関係を散布図として図 5 に示す。症例が少 なくはっきりとした関係はみられないが，標準 偏差 $\sigma_{T i}$ の推定值 $\hat{\sigma}_{T i}$ の大きなものは大きな誤 差を含むことがあるといら傾向がみられた.

恒 常 法

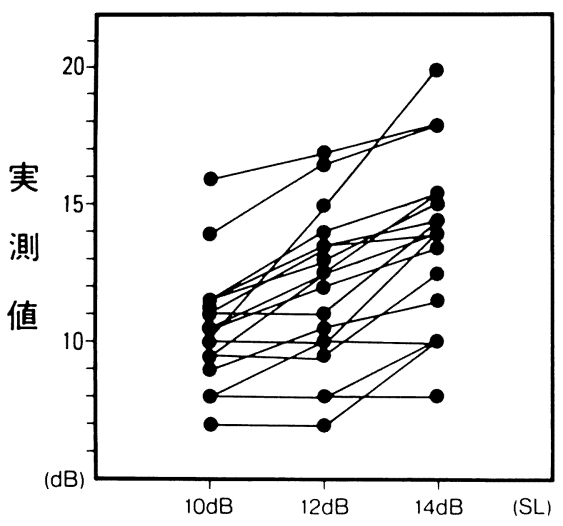

擬似耳鳴強度 $\quad(n=16)$
4) 小括

恒常法による耳鳴ラウドネス検査法を考案し, 聴力正常男子 20 名 20 耳に対し擬似耳鳴を与光, そのラウドネスを恒常法および標準耳鳴検査法 1984のラウドネス・バランス検査（標準法）で 測定し, 以下の結果を得た.

(1)恒常法による検査法が標準耳鳴検査法より も測定值が安定しており，2 $\mathrm{dB}$ 位の変化は捉 えることができたが，標準法ではできなかった。

(2)恒常法は被検者の識別や弁別の確かさを量

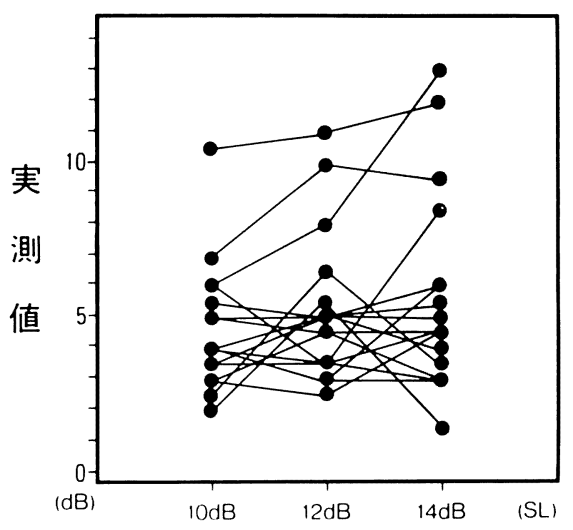

擬似耳鳴強度 $\quad(n=16)$

図 3 凝似耳鳴強度と恒常法の実測值 $\hat{\mu}_{T}-\hat{\mu}_{0}$ 扣よび標準耳鳴検査法の ラウドネス・バランス検査の実測值 $\tilde{\mu}_{T}-\tilde{\mu}_{0}$ の関係

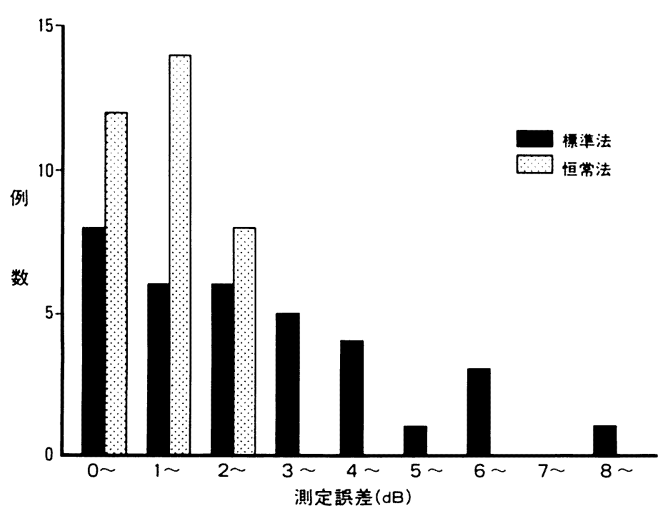

図4 耳鳴ラウドネスの測定䛊差 $\varepsilon_{12}, \varepsilon_{14}$ の ヒストグラム

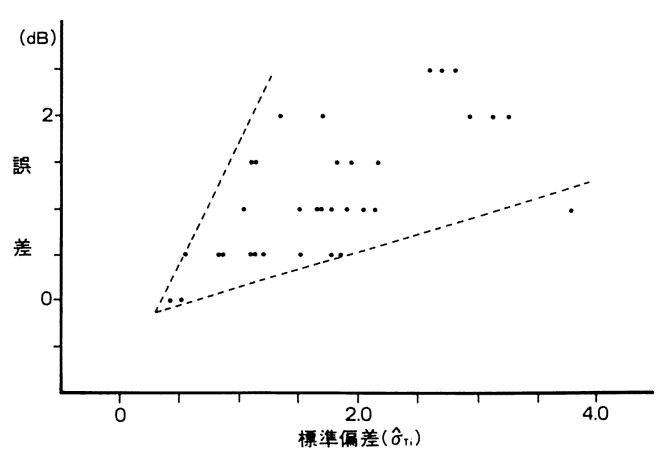

図 5 精神測定関数の標準偏差 $\hat{\sigma}_{T i}$ と恒常法に よる実測值の誤差 $\varepsilon_{12}, \varepsilon_{14}$ との関係 
向として表すことができる.

(3)恒常法による実測值が標準法の場合より高 值となった。

\section{5 ）考 察}

\section{〔測定精度〕}

擬似耳鳴を $2 \mathrm{~dB}$ ステップで増音していき， ラウドネスを測定したところ，恒常法は注ぼそ の変化を捉えることができたが，標準法の場合 は $1 \mathrm{~dB}$ ステップで測定しても $2 \mathrm{~dB}$ の変化を捉 えるのは難しい.

また測定の安定性を䛊差として表し，それと 精神測定関数の標準偏差 $\hat{\sigma}_{T i}$ との関係をみると $\hat{\sigma}_{T i}$ が大さくなるにつれて, 誤差の分布幅が大 きくなった。

コンピュータを用いることにより，高度な検 查が非常に簡便に，かつ検者の意志のまったく 入る余地の無い測定が可能になり, 安定した データが得られるようになった，それとともに 被検者の弁別や識別の確かさを量として表現す ることができ，これを利用して被検者側の問題 や耳鳴と検査音の関係の問題に対して検討する ことができる.

〔耳鳴ラウドネス值】

この実験で恒常法で実測を行った方が精度が 向上することが示されたがそれだけでなく，擬 似耳鳴による実験で標準法では平均 $5.0 \pm 2.4$ $\mathrm{dBSL}$ (平均 $\pm \mathrm{SD}$ ) で, 恒常法での平均 $12.0 \pm$ $2.9 \mathrm{dBSL}$ と大きな差を認めた $(\mathrm{p}<0.01)$. その 理由は SL 值の最小可聴閾值の求め方が違うた めと思われ, 閾值の差を求めてみたところ恒常 法と上昇法の差の平均は $3.2 \pm 3.8 \mathrm{~dB}$ で, 上昇 法の方が高值である結果となった。平均值だけ でみるのは問題があるが, 最小可聴閾值の差を 差し引いても恒常法と標準法の耳鳴ラウドネス の実測值 (HL 值) の間に $3.8 \mathrm{~dB}$ の差が存在す る. 但し, 有意差は認めなかった。

その原因は今後検討を要するが，その因子と して，以下に示す事柄が考えられる.
〔耳鳴ラウドネス測定に括ける問題点〕

A. 検查法に打ける問題点

(1)比較音の呈示順序, 呈示間隔による系列効 果 (時間順序誤差など). (2)検者の違いにより 生じる操作手順の違いによる誤差. (3)検査音の 系列を幾度か呈示する度に被検者の判断に変動 があるのが普通であるが変動の範囲内でどの值 を検者が実測值とするかという検査データ選択 に起因する誤差. (4)耳鳴と検査音の音色やピッ チは, 通常は異なっているが音刺激と耳鳴刺激 といら異種のもの同士の比較困難に起因する誤 差. (5)耳鳴音の音色やピッチの変動による判断 の䛊差. 6検査刺激の耳鳴による情報伝達の障 害による誤差. (7)検查音による residual inhibition (RI) やマスキングによる誤差.

B. 被検者に起因する問題点

(1)感音性難聴耳に生じる補充現象, などがあ げられるが，我々は，まずAの問題点を解決す るためにコンピュータを使用した恒常法を考案 した．測定法の理論から考光ると当然のことで あるがその方法により A(1)からA(3)までの問題 点は, ほぼ解決することができた. A(4)の問題 点の解決法として今泉らの考案した 1 対比較法 による耳鳴検査法である PAST 法10)などを使 って, 耳鳴の詳細なピッチの測定を行ったとし ても，A６の情報伝達の障害11)（耳鳴と検査音 の類似性が高いと耳鳴が検査音に干渉しやすい と考える）はすべての場合に問題となり耳鳴検 査の結果に影響を与える.

A(7)の RI は, 耳鳴の最小マスキングレベル $(\mathrm{MML})$ 上 $10 \mathrm{~dB}$ の刺激 1 分間で約70\%の出現 率をみるとされている，耳鳴マスキングレベル が MML 以下では汪とんど起こらないとされ ており，耳鳴のマスキングが 1 分以下の場合は 時間依存性と考兄られている．また RI 持続時

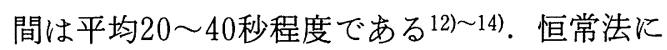
よる耳鳴ラウドネス検査の刺激持続時間は 1 秒 であるので汪とんど RI の影響はないと思われ るが，刺激音のレベルはランダムの順序で呈示 されるので急に高レベルの刺激が呈示されるこ 
とがあるので，高レベルの刺激で RI がおこり 次の刺激が呈示された際に誤った判断がなされ る可能性がある. B(1)の項目については実験 4 にて後述する.

\section{《実験 $2 》$}

耳鳴ラウドネス値の検者による違い（恒常法 と標準法の比較）についての実験

一 2 人の検者による耳鳴ラウドネス実測値の 違い一

1) 目 的

耳鳴ラウドネス測定值が検者の違いによりど のよらに変化するかを検討するため, 同一被検 者に対し 2 人の検者で耳鳴ラウドネス測定を行 った。

\section{2) 方 法}

[対 象]

34 歳より 83 歳, 平均59歳の耳鳴患者 12 名 12 耳. [実験機器]

実験 1 に同様であるが機器の接続法をブロッ ク・ダイアグラム（図6）に示す.

\section{[実験方法]}

自覚的に変化の無い耳鳴患者に対し検者 $\mathrm{A}$, $\mathrm{B}$ の 2 名で耳鳴ラウドネスの測定を, 患側評価 で標準法と恒常法の 2 つ方法で施行した. 但 し, 同じ方法で行ら際, できるだけ時間をあけ ずに連続して行った．恒常法は前述した方法で， 刺激系列は $1 \mathrm{~dB}$ ステップの10音で各水準の刺 激の呈示回数は 10 回とした。標準法は $5 \mathrm{~dB}$ ス テップの上昇法で施行した.すべて SL 值で求 め, 最小可聴閾値測定は恒常法の場合は同様に
恒常法で, 標準法の場合は $5 \mathrm{~dB}$ ステップの上 昇法で施行した。

検者 $\mathrm{A}$ は聴覚実験の経験年数10年の研究者で, 検者 $\mathrm{B}$ は経験年数 3 年の聴覚検査技師である.

\section{3 ) 実験結果}

〔最小可聴間値〕

SL 值の基準となる最小可聴間値のそれぞれ の検者の度数分布を図 7 に示す. 上昇法による 最小可聴間值測定の場合, 恒常法による方法も 検者間では有意な差は認めなかった。ところが 測定法の違いにより実測值に, 検者 $\mathrm{A}$ の場合 $\mathrm{p}<0.05$, 検者 $\mathrm{B}$ の場合 $\mathrm{p}<0.01$ で有意に恒常 法の方が最小可聴間值が小さくなった.

[耳鳴ラウドネス]

耳鳴ラウドネス実測值の分布は, 図 8 のよう にそれぞれの検者での実測值は, 標準法の場合 も恒常法の場合もピークの位置は異なっている が，標準法ほど明確な差はない。検者 $\mathrm{A}, \mathrm{B}$ と もに恒常法による実測值の方が, 標準法の場合 より有意に大きな值を示している $(\mathrm{p}<0.01)$.

最小可聴閾値と耳鳴ラウドネス値の検者間の 差の分布を, 標準法と恒常法の場合の両方を求 めてみた. 図 9 に示す結果をみると明らかなよ らに, 最小可聴閾値は標準法も恒常法も検者間 の差は $2 \mathrm{~dB}$ 未満がほとんどであるが，耳鳴ラ ウドネス実測值においては, 恒常法の場合は半 数以上は差が $2 \mathrm{~dB}$ 末満に分布して括り, 平均 $1.9 \pm 1.0 \mathrm{~dB}(\mathrm{~m} \pm \mathrm{SD})$ となっている. 一方標準 法では $4 \sim 6 \mathrm{~dB}$ が過半数を占め, 平均 $4.8 \pm 2.6$ $\mathrm{dB}$ となっている，標準法の場合の方が検者間

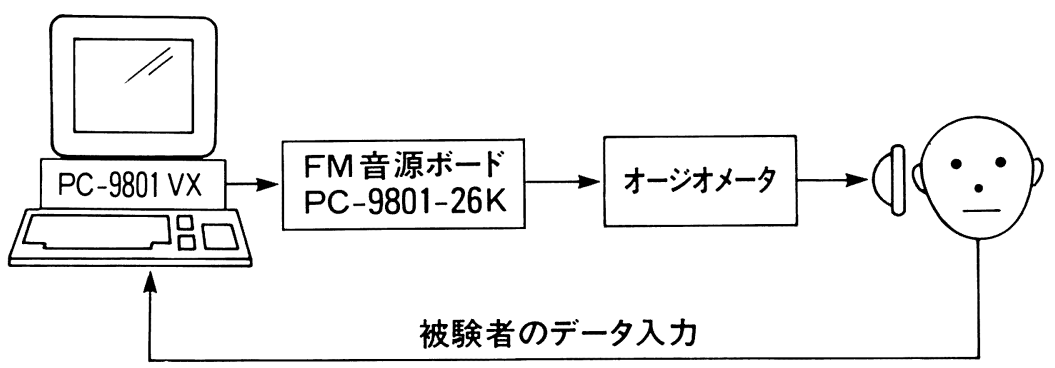

図 6 耳鳴ラウドネス測定のための実験装置のブロック・ダイアグラム 
の差が有意に大きいといら結果になった（p< 0.05).

〔耳鳴ラウドネス値の測定法による違い]

この実験でも検者 $\mathrm{A}$ と検者 $\mathrm{B}$ の耳鳴ラウドネ スの実測值の平均を表 2 に示す. 耳鳴ラウドネ スは両者の測定值ともに恒常法による実測值の 方が高值になっている. 平均值だけで判断する のは多少危険であるが，やはり最小可聴閾値の 差以上に恒常法の方が高值になった.
4) 小括

2 名の検者 $\mathrm{A}, \mathrm{B}$ で12名の耳鳴患者12耳に対 して耳鳴ラウドネスを恒常法および標準法で測 定し, 以下の結果を得た。 (1)最小可聴閾值測定 では，上昇法（標準法では上昇法を用いた）， 恒常法ともに検者 $\mathrm{A}, \mathrm{B}$ 間の差は法とんど生じ なかった. (2)最小可聴閾值は恒常法の方が上昇 法に比べ平均 2〜 $3 \mathrm{~dB}$ 小さい值になった. (3)耳 鳴ラウドネス値は, 標準法の場合, 検者 $\mathrm{A}, \mathrm{B}$

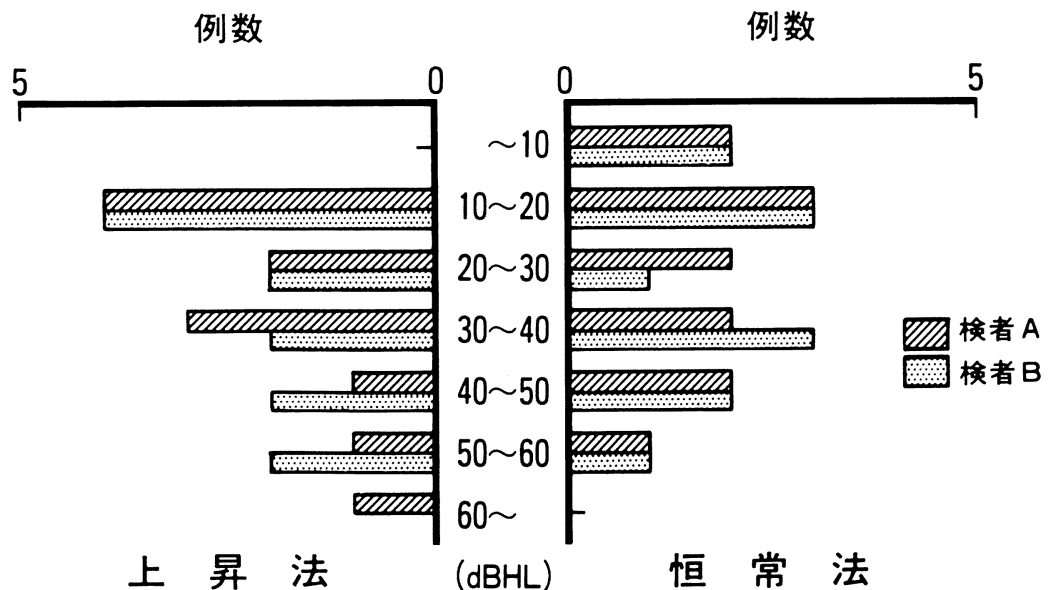

図 7 検者 $\mathrm{A}, \mathrm{B}$ による最小可聴閾値の実測值のヒストグラム

左図：上昇法による最小可聴閾値実測值 $\tilde{\mu}_{0}$, 右図 : 恒常法による最小可聴閾值実測值 $\hat{\mu}_{0}$.

例数

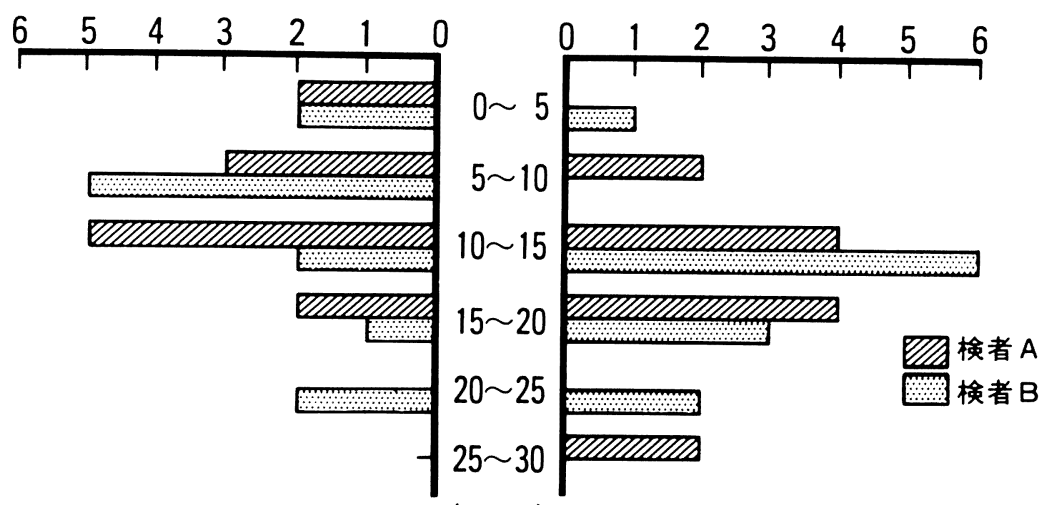

標 準 法 (dBSL) 恒 常 法

図 8 検者 $\mathrm{A}, \mathrm{B}$ によ鵈ラウドネスの実測值のヒストグラム

左図: 標準法による耳鳴ラウドネス実測値 $\tilde{\mu}_{T}-\tilde{\mu}_{0}$, 右図 : 恒常法 $\hat{\mu}_{T}-\hat{\mu}_{0}$ 恒常法では検者 $\mathrm{A}, \mathrm{B}$ と もにピークが一致. 両検者とも恒常法による実測值の方が有意に高値. 
間で $5 \mathrm{~dB}$ 程度の差を生じることが多く, 恒常 法の場合は，ほとんどが $5 \mathrm{~dB}$ 末満であった。

(4)耳鳴ラウドネス值は, 恒常法による実測值 $\hat{\mu}_{T}-\hat{\mu}_{0}$ (表 1 参照) は, 標準法の実測値 $\tilde{\mu}_{T}-\tilde{\mu}_{0}$ より有意に高值を示した。耳鳴ラウドネスの HL 值 $\hat{\mu}_{T}$ と $\tilde{\mu}_{T}$ の場合は, 有意差はなかったが 平均で比較するとまだ恒常法 $\hat{\mu}_{T}$ の方が高値を 示した.

5 ) 考 察

上昇法で最小可聴閾値を測定する場合は検者
間ではあまり大きな差は生じないが，標準法に よる耳鳴ラウドネス值になると $\pm 5 \mathrm{~dB}$ 程度の 差を生じることが多くなる. 耳鳴ラウドネス值 は，10 dBSL 以下のことが多いので無視でき ない差である. 被検者の検査刺激音に対する反 応を抽出した場合, どの水準を等価値として検 者が判断するかといら問題によると考えられる. また被検者の判断のばらつきもその差を生じさ せることに関与していると考えられる.

耳鳴ラウドネス実測值の信頼性について神崎

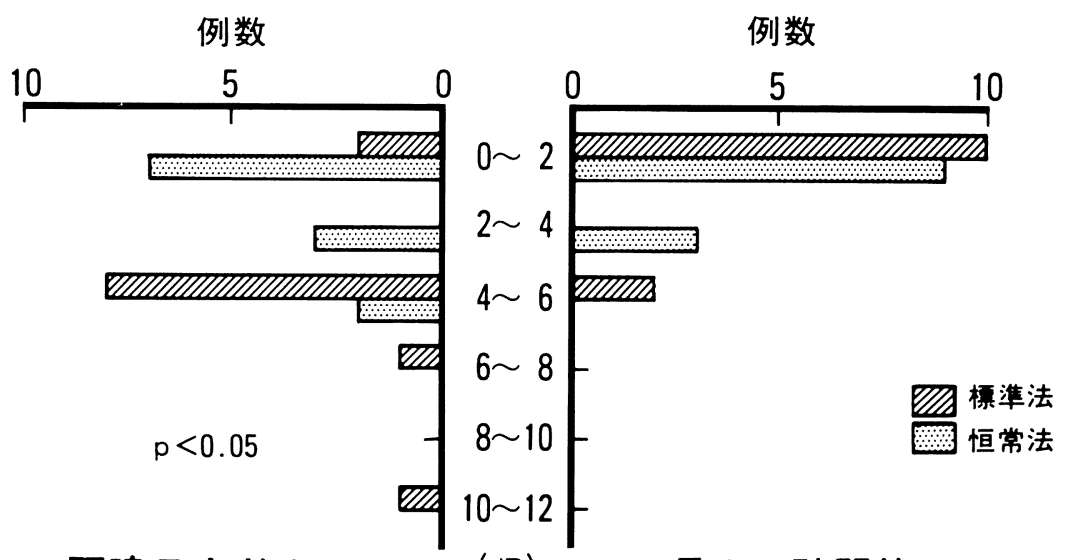

耳鳴ラウドネス

最小可聴闘値

図 9 検者 $\mathrm{A}, \mathrm{B}$ の最小可聴閾值の差と耳鳴ラウドネス値の差 最小可聴間值では恒常法と標準法のいずれの場合でもばらつきは小さいが， 耳鳴ラウドネス值は恒常法の方が小さい.

表 2 検者 $\mathrm{A}, \mathrm{B}$ の耳鳴ラウドネスと最小可聴閾値の 実測值の平均と標準偏差

\begin{tabular}{|c|c|c|c|}
\hline & & 検者 $\mathrm{A}$ & 検者B \\
\hline 耳鳴ラウドネス & $\begin{array}{l}\text { 標準法 } \\
\text { 恒常法 }\end{array}$ & $\begin{array}{l}7.9 \pm 4.8^{*} \\
14.6 \pm 6.3\end{array}$ & $\begin{array}{l}8.5 \pm 6.8 \\
14.6 \pm 5.0 \text { (dBSL) }\end{array}$ \\
\hline 最小可聴闘値 & $\begin{array}{l}\text { 上昇法 } \\
\text { 恒常法 }\end{array}$ & $\begin{array}{l}29.6 \pm 15.7 \\
26.6 \pm 15.2\end{array}$ & $\begin{array}{l}29.6 \pm 15.2 \\
27.1 \pm 15.9(\mathrm{dBHL})\end{array}$ \\
\hline
\end{tabular}


ら15) は, 自覚的に変化の無い耳鳴患者38名に 対して 3 時間扣きに 2 回ラウドネス・バランス 検査を行い，34例が $5 \mathrm{~dB}$ 以内の変動で 4 例が $10 \mathrm{~dB}$ 以上の変動がみられたので, $10 \mathrm{~dB}$ の変 化は測定の変動 (variation) と考皃た方が無難で あると述べている．また耳鳴ラウドネス值の諸 家の報告は，10 dBSL 以下が Tyler ら ${ }^{3)}$ の集計 では71\%，片山ら ${ }^{16)} 87.4 \%$, 杉本ら ${ }^{17)} 72.5 \%$, 卜部18) $91.2 \%$, 山下ら ${ }^{19)} 87 \%$, Goodwin $5^{20)}$ $78.5 \%$, Vernon ${ }^{21)} 69 \%$, 当論文の 149 耳では 89.9\%である. ほとんどの症例が測定の变動以 内であり, 現在のバランス法では客観的に耳鳴 ラウドネスを正確に評価することが困難といえ る.耳鳴ラウドネスのよらな小さな值を評価す る場合は, 現法よりも精度の優れた聴覚心理学 的手法を用いる必要がある.

恒常法による耳鳴ラウドネス測定は精度が高 く, 検者の違いにも安定していることが実験 1 扣よび実験 2 で示された，今後は，耳鳴ラウド ネスの評価には恒常法のよらな判断発見法によ る測定法が用いられるべきであると考学る.

《実験 $3 》$

検査法の違いによる実測值の差の生じる理由 の解明

ーラウドネス・バランス検査のシミュレーシ ョン実験による実証一

第II章の実験 1 および㬰験 2 で示したように 擬似耳鳴のラウドネスも, 実際の耳鳴のラウド ネスも恒常法による実測値 $\hat{\mu}_{T}-\hat{\mu}_{0}$ が標準法の 実測値 $\tilde{\mu}_{T}-\tilde{\mu}_{0}$ に比較して有意に高值になるこ とを述べた。 またその差は, 上昇法と恒常法に よる最小可聴閾值の差 $\tilde{\mu}_{0}-\hat{\mu}_{0}$ より大きく

$$
\left(\hat{\mu}_{T}-\hat{\mu}_{0}\right)-\left(\tilde{\mu}_{T}-\tilde{\mu}_{0}\right)>\tilde{\mu}_{0}-\hat{\mu}_{0}
$$

といらことである.つまり $\hat{\mu}_{T}>\tilde{\mu}_{T}$ となる場合 が多いということになる．恒常法による耳鳴 ウドネス值が標準法よりも大きくなるのは, 最 小可聴閾値の違いだけが原因とはいえない。

恒常法とは，被検者の反応母集団が心理連続 体上で正規分布 $N\left(\mu, \sigma^{2}\right)$ すると仮定し, 反応 の任意抽出により精神測定関数 $N\left(\hat{\mu}, \hat{\sigma}^{2}\right)$ を推
定し，その平均值 $\hat{\mu}$ を求めるものであるが，恒 常法による実測值が標準法によるものより大き くなるのは，検者の検査手技や判断のために起 こるものか，標準法の測定法が被検者の判断の 任意抽出でないために起こるものなのかを，検 討するために以下のシミュレーション実験を施 行した.

被検者の判断の抽出法にかかわらず（つまり 刺激の呈示の順序にかかわらず), 比較判断の 法則に従う被検者としてのコンピュータモデル を作成して，それに対して標準法のラウドネス ・バランス検査のシミュレーションを施行し, 耳鳴患者の耳鳴ラウドネス実測值と比較した.

1) 目 的

恒常法による耳鳴ラウドネス実測值が大きく なるのは，検者の検查手技拈よび判断に原因が あるのか，被検者の判断に原因があるのか，ま た最小可聴閾値測定と耳鳴ラウドネス測定のい ずれに原因があるのかを検討することを目的と する.

2) 方 法

〔被検者のコンピュータ・モデルの作製】

まずラウドネス・バランス検査のシミュレー ションを行らために, 刺激に対する反応が精神 測定関数に忠実に従らモデルの作製から行わな ければならない，精神測定関数は，正規分布 $N\left(\mu, \sigma^{2}\right)$ を積分した累積正規分布関数である. 要するに $\mu, \sigma$ のつのパラメータによって決 定するものであるが，検者にその值がわからな いようにするために自動設定にしなければなら ない。しかし現実とかけ離れた設定值であると 耳鳴患者のデータと比較することができない． そこで耳鳴患者149耳の恒常法による耳鳴ラウ ドネス測定時の図10に示すパラメータ（最小可 聴閾值 : $\hat{\mu}_{0}$, 耳鳴ラウドネス值 : $\hat{\mu}_{T}$, および精 神測定関数の標準偏差 : $\left.\hat{\sigma}_{i}, \quad \hat{\sigma}_{T i}\right)$ の分布とほぼ 同じような分布となるように，乱数を発生させ て自動設定されるようにプログラムした. 
〔ラウドネス・バランス検査のシミュレー ション]

コンピュータの被検者モデルを用いたシミュ レーションのフローチャートを図11に示す．プ ログラム上，比較判断の法則の刺激連続体上の $S_{i}$ に変数 ATT (ATTenuator 值) を心理連続 体上の $R_{i}$ に变数 $\varepsilon_{i}$ (心理的变動に相当する) を 割り当てた。 $\varepsilon_{i}$ は $N\left(0, \sigma^{2}\right)$ の正規分布に従ら乱 数であり $\mathrm{S}_{i}$ が測定ステップ $\mathrm{ST}$ ずつ変化する 度に $R_{i}\left(\mathrm{ATT}+\varepsilon_{i}:\right.$ 心理連続体上の值) が決定 され，それが閾值 $\mu_{0}\left(\right.$ (あるいは $\left.\mu_{T}\right)$ を越えると インジケータが点灯し，閾值より小さくなると インジヶータが消灯する．インジヶータが点灯 した状態は，心理実験で被検者が，刺激が検出 されたあるいは刺激が等価值を越えたと判断し たことに相当し，インジケータが消灯した状態 はその逆の事象が起こった場合である。

検者は，アッテネータの代わりにマウス（コ

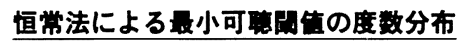

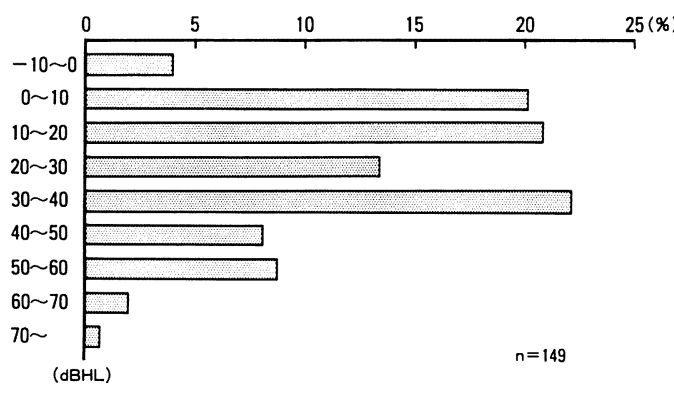

ンピュータの連続量の入力装置）により ATT 值を変化させインジケータの状態で $\mu_{0}$ を推定 する.この方法を 2 回繰り返し自動設定された 最小可聴閾值と耳鳴ラウドネス值を推定する. 最小可聴閾值と耳鳴ラウドネス値の両者とも上 昇法で求めた。耳鳴ラウドネスは，SL 值で求 めた。

ラウドネス・バランス検査のシミュレーショ ンを検者 $\mathrm{A}, \mathrm{B}$ の 2 者で施行し, 耳鳴患者の標 準法および恒常法で実測した耳鳴ラウドネス值 と比較した。

3 ) 結 果

〔最小可聴間值〕

図12に耳鳴患者149例の恒常法と上昇法につ いての最小可聴閾值の関係を示す. 平均で 2 $\mathrm{dB}$ 恒常法の方が有意に低值になっている. 図 13に示すシミュレーション実験の場合の最小可 聴閾值の実測值（上昇法による $\tilde{\mu}_{0}$ ）と絶対閾

恒常法による耳唺ラウドネスの度数分布

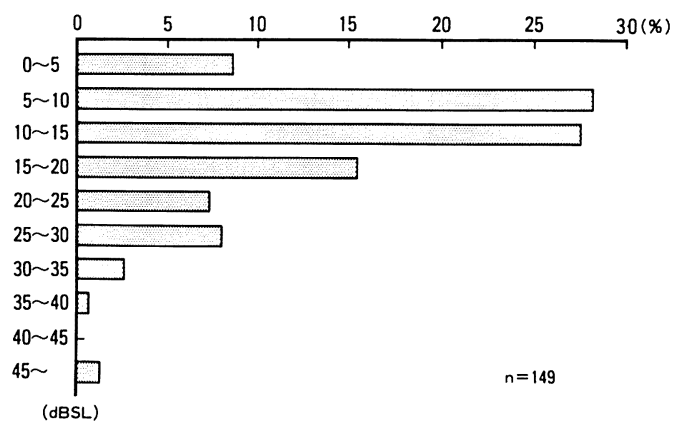

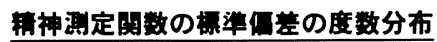

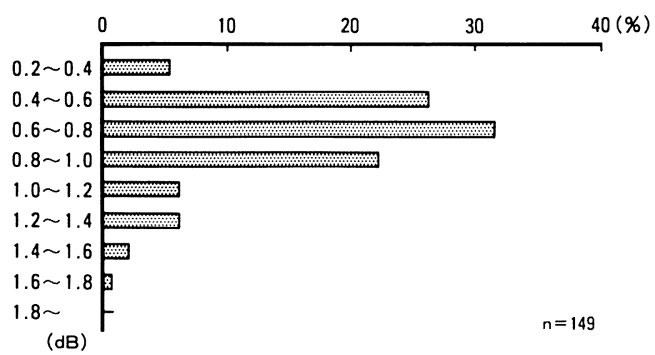

図10 149耳における恒常法による耳鳴ラウドネスの度数分布および精神測定関数の 各パラメータの度数分布 
（設定値 $\mu_{0}$ ）の関係とあまり大差はない，検者 $\mathrm{A}$ で実測值が $2.8 \mathrm{~dB}$ 大きく, 検者 $\mathrm{B}$ で実測值 が $2.6 \mathrm{~dB}$ 大きくなっている．検者間でも実測 值の差は，ほとんど認められない。

[耳鳴ラウドネス値]

耳鳴ラウドネス値の標準法と恒常法の関係 （図14）をみると大きな差が認められる。耳鳴
患者の耳鳴ラウドネスでは，恒常法の実測値が 標準法よりも, 平均で $8.6 \mathrm{~dB}$ 高値になってい る.この図では繁雑すぎてわかりにくいので標 準法の実測值レベル別に分類したものを図15に 示す. 標準法の 1 水準のレベルに対して恒常法 による実測值は幅が約 $30 \mathrm{~dB}$ にも及んでおり， かつ恒常法の方が有意に高值を示しているのが

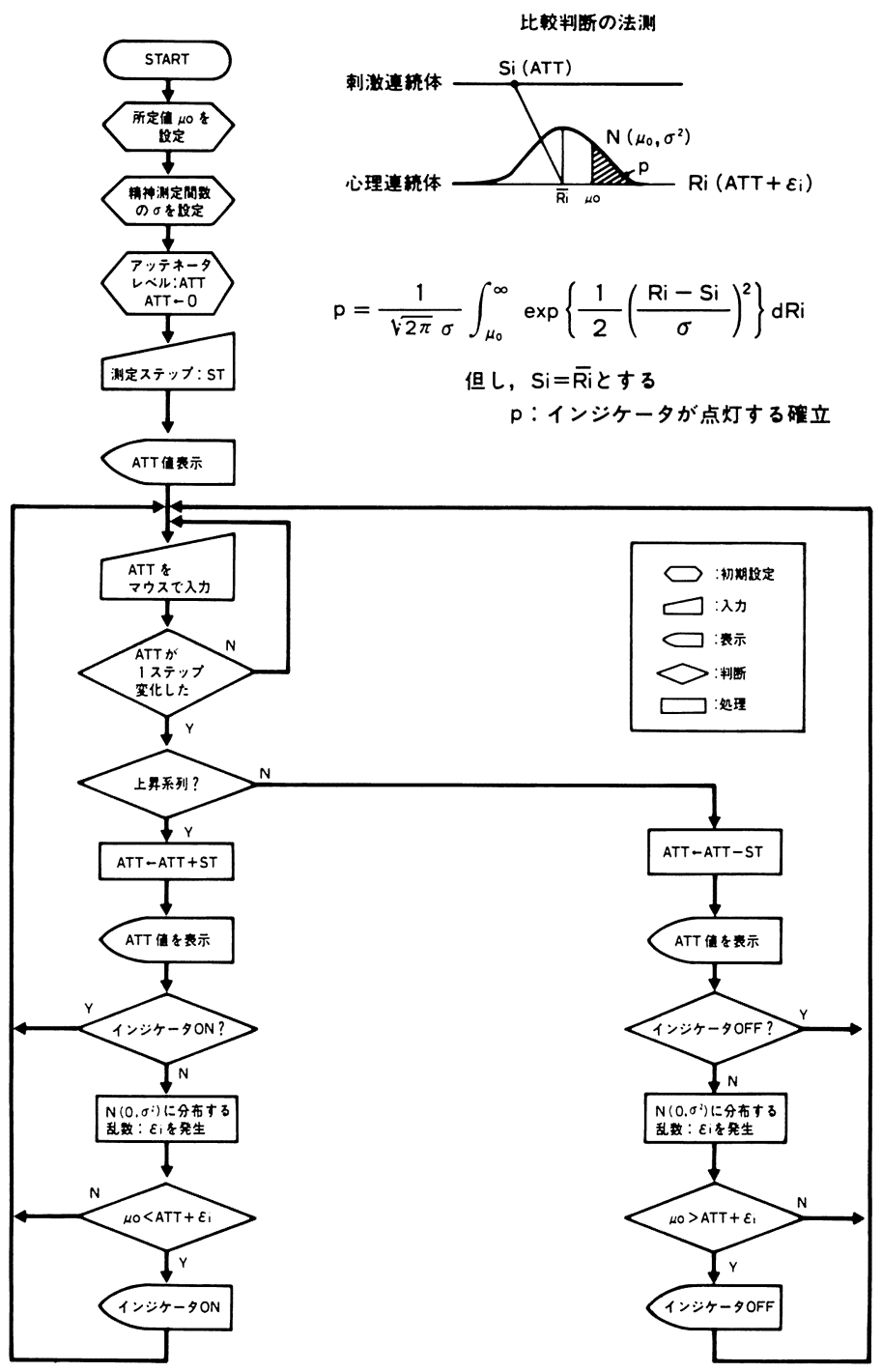

図11 ラウドネス・バランス検査のコンピュータ・シミュレーション・モデルのフローチャート

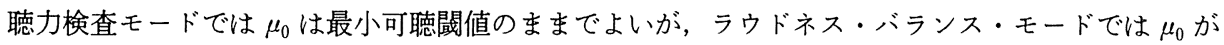
$\mu_{T}$ におき代わり結果は $\tilde{\mu}_{T}-\tilde{\mu}_{0}$ で表示される. 
わかる。

ラウドネス・バランス検査のシミュレーショ ソの場合を図16に示す。但し，結果は SL 值 $\left(\hat{\mu}_{T}-\hat{\mu}_{0}\right)$ で表した。検者Aは，実測值（標準法 の実測值に相当）が設定值（恒常法の実測值に

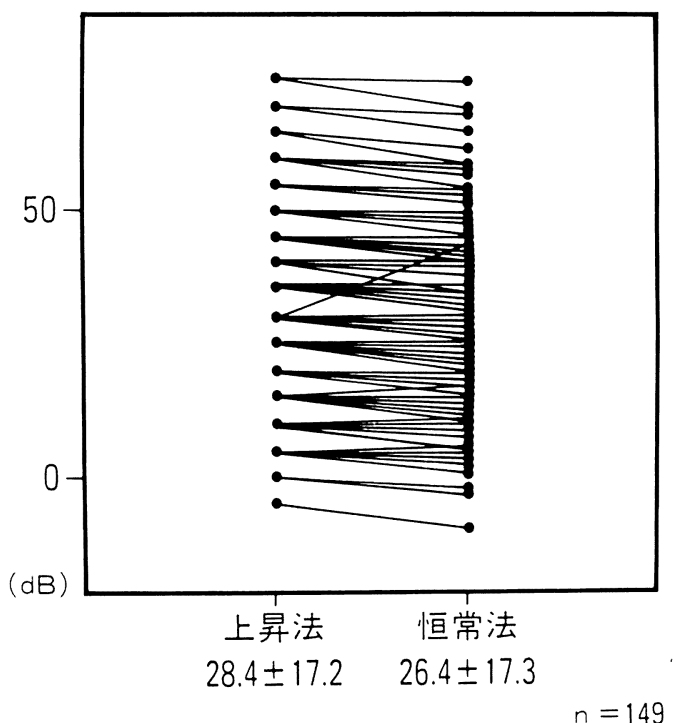

図12 耳鳴患者に打ける最小可聴閾值の上昇法と 恒常法との比較

上昇法の平均は $28.4 \pm 17.2 \mathrm{dBHL}$ (平均 $\pm \mathrm{SD}$ ) dBHL．恒常法は $26.4 \pm 17.3$ dBHL.
相当： $\mu_{T}-\mu_{0} ）$ に比較して $5 \%$ の危険率で有 意に低值を示したが，耳鳴患者の $8.6 \mathrm{~dB}\left(\hat{\mu}_{T}-\right.$ $\hat{\mu}_{0}$ と $\tilde{\mu}_{T}-\tilde{\mu}_{0}$ の差の平均）と違い平均の差がわ ずかに $0.7 \mathrm{~dB}$ であった。検者 Bに関しては, 平均で差は認められなかった。検者 $\mathrm{A}, \mathrm{B}$ とも

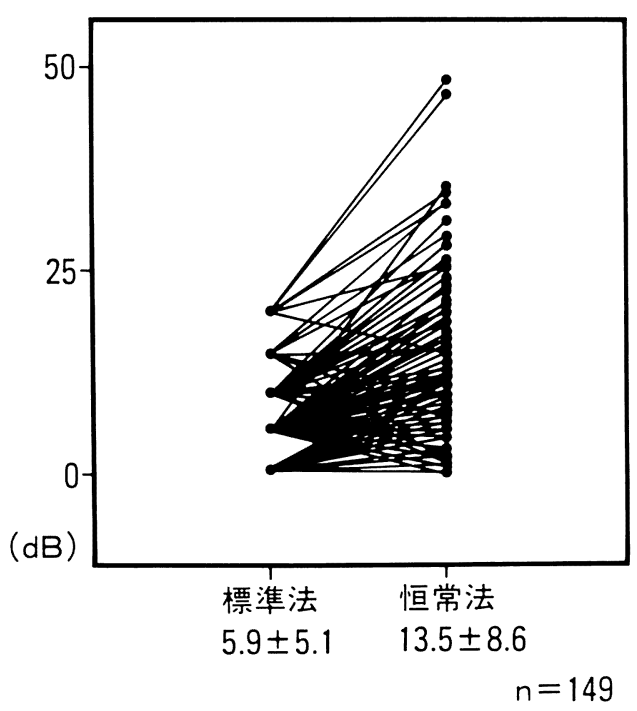

図14 耳鳴患者に扩ける標準法と恒常法による 実測值の比較

標準法の平均は 5.9 $55.1 \mathrm{dBSL}$. 恒常法は 13.5 $\pm 8.6 \mathrm{dBSL}$.
検者 $A$

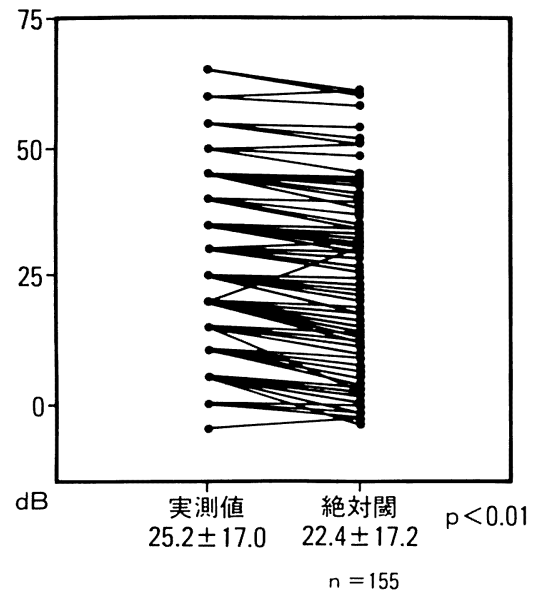

検者 B

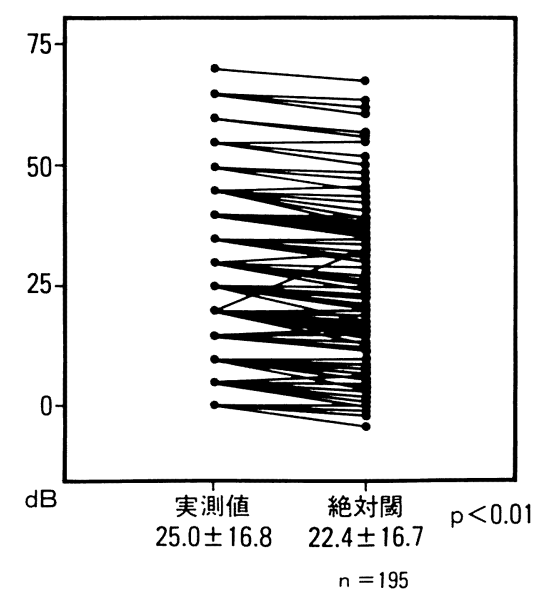

図13 最小可聴閾值測定のシミュレーションによる $\tilde{\mu}_{0}$ とそのときの設定值 $\mu_{0}$ の関係 左図は検者 $\mathrm{A}$, 右図は検者 $\mathrm{B}$. 

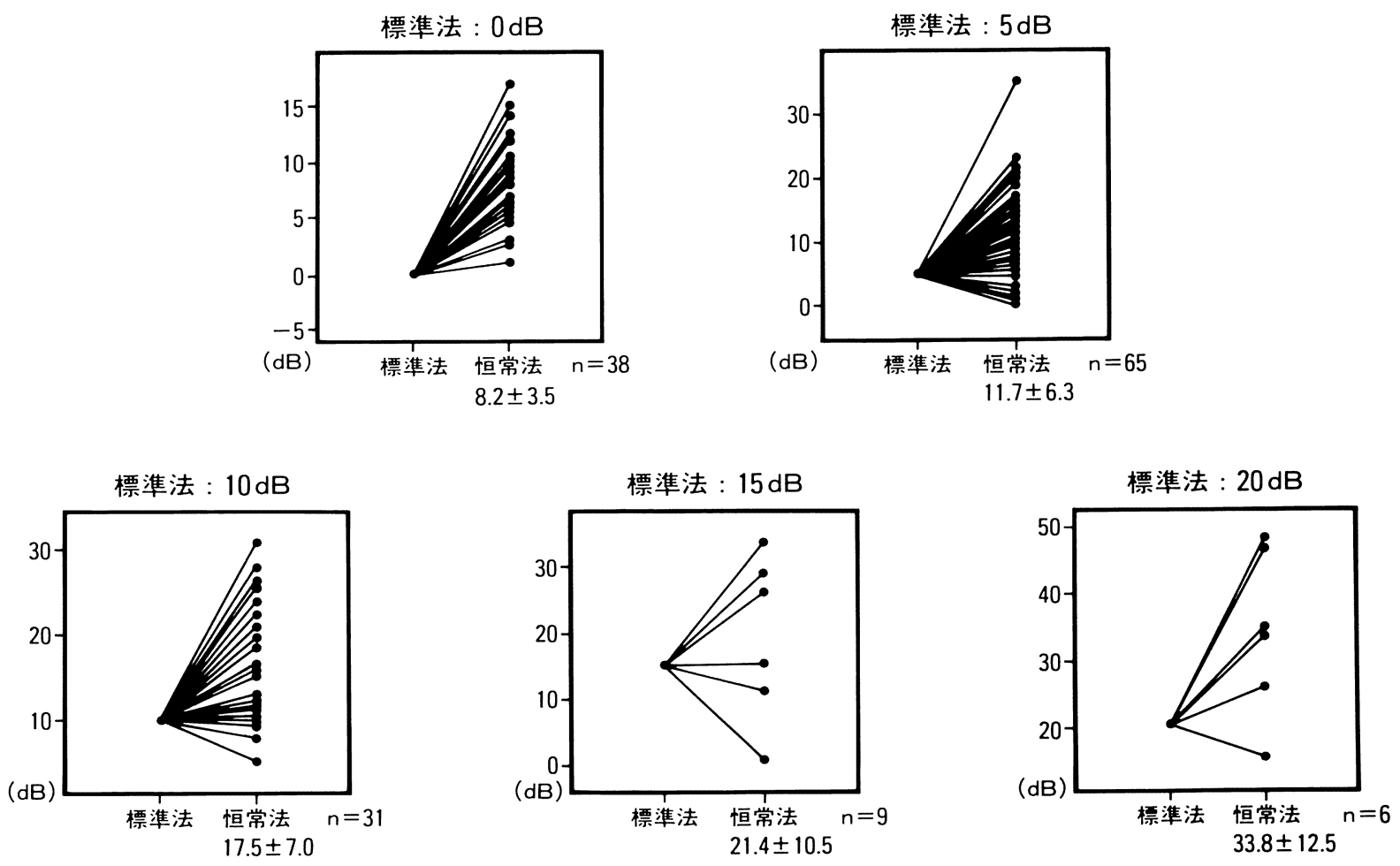

図15 図14を標準法の実測值で分類した図 
に両者に差はほとんど認めないといらことがで きる.施行回数が多い検者 Bのデータを実測值 で分類した図を図17に示す. 1 水準の実測值に 対して $\pm 5 \mathrm{~dB}$ 以内に設定值が分布しており実 測値が設定値の平均にほぼ等しい。

またシミュレーション実験の耳鳴ラウドネス 設定值 $\mu_{T}-\mu_{0}$ と標準法の実測值 $\tilde{\mu}_{T}-\tilde{\mu}_{0}$ の相関 係数は, 検者 $\mathrm{A}$ の場合は 0.91 , 検者 $\mathrm{B}$ の場合 は0.95であり, 耳鳴患者の $\hat{\mu}_{T}-\hat{\mu}_{0}$ と $\tilde{\mu}_{T}-\tilde{\mu}_{0}$ の 相関係数 0.64 より強い相関を認めた（図18）.

4) 小 括

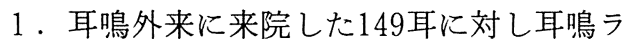
ウドネス測定を施行したところ以下の結果を得 た。

(1)最小可聴閾値は, 恒常法による実測値 $\hat{\mu}_{0}$ が上昇法 $\tilde{\mu}_{0}$ よりも平均で約 $2 \mathrm{~dB}$ 低值を示した

(2)耳鳴ラウドネスは標準法による実測值 $\tilde{\mu}_{T}$ 一 $\tilde{\mu}_{0}$ よりも，恒常法による実測值 $\hat{\mu}_{T}-\hat{\mu}_{0}$ の方 が，平均で $6.6 \mathrm{~dB}$ 高值を示し有意差を認めた.

2. Thurstone の比較判断の法則に刺激の呈 示順序にかかわらず，いかなる場合も従う被検 者のコンピュータ・モデルに対して, 検者 $\mathrm{A}$, B 2 名の検者がラウドネス・バランス検査のシ ミュレーションを施行して以下の結果を得た。

検者 $\mathrm{A}$

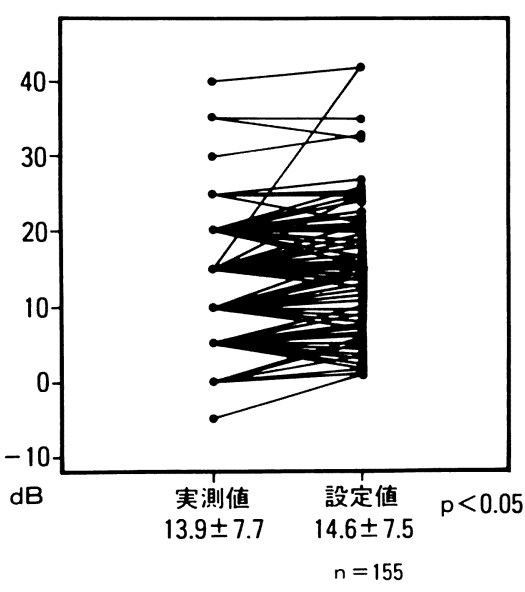

(1)耳鳴患者の場合と同様に，最小可聴閾值測 定は検者 $\mathrm{A}$ は絶対閾（設定值 $\mu_{0}$ ）より実測値 $\tilde{\mu}_{0}$ が平均 $2.6 \mathrm{~dB}$ 高值を示し, 検者 $\mathrm{B}$ は $2.8 \mathrm{~dB}$ 高值を示した。検者 $\mathrm{A}$ と検者 $\mathrm{B}$ の間には有意差 はなかった。

(2)耳鳴患者の場合と違い，耳鳴ラウドネス測 定值は検者 $\mathrm{A} か ゙$ 当価值（設定值 $\mu_{T}-\mu_{0}$ ）より 実測值 $\tilde{\mu}_{T}-\tilde{\mu}_{0}$ の方が $0.6 \mathrm{~dB}$ しか高值を示さず， 検者 Bでは差はなかった。

(3)コンピュータ・モデルでは $\mu_{T}-\mu_{0}$ と $\tilde{\mu}_{T}-\tilde{\mu}_{0}$ の間に有意差を示さないのに，耳鳴患者では耳 鳴ラウドネス值の恒常法による実測值 $\hat{\mu}_{T}-\hat{\mu}_{0}$ が標準法の実測值 $\tilde{\mu}_{T}-\tilde{\mu}_{0}$ より高値を示すのは, 刺激の与え方の違い，つまり系列効果によるも のと思われる。

5 ) 考察

このコンピュータによる被検者モデルは，反 応母集団よりの抽出法にかかわらず比較判断の 法則に従うようにプログラムされている。最小 可聴閾值測定においてシミュレーションの場合 の実測值 $\tilde{\mu}_{0}$ と設定値 $\mu_{0}$ の関係と，耳鳴患者の 標準法の実測值 $\tilde{\mu}_{0}$ と恒常法の実測値 $\hat{\mu}_{0}$ の関係 は（図12，図13），両者の場合に注涪同じょら な関係になっているので最小可聴閾值測定の場

図16 ラウドネス・バランス検査のコンピュータシミュレーション 設定值 $\mu_{T}-\mu_{0}$ と実測值 $\tilde{\mu}_{T}-\tilde{\mu}_{0}$ の関係. 右図は検者 $\mathrm{A}$ ，左図は検者 $\mathrm{B}$ の場合. 

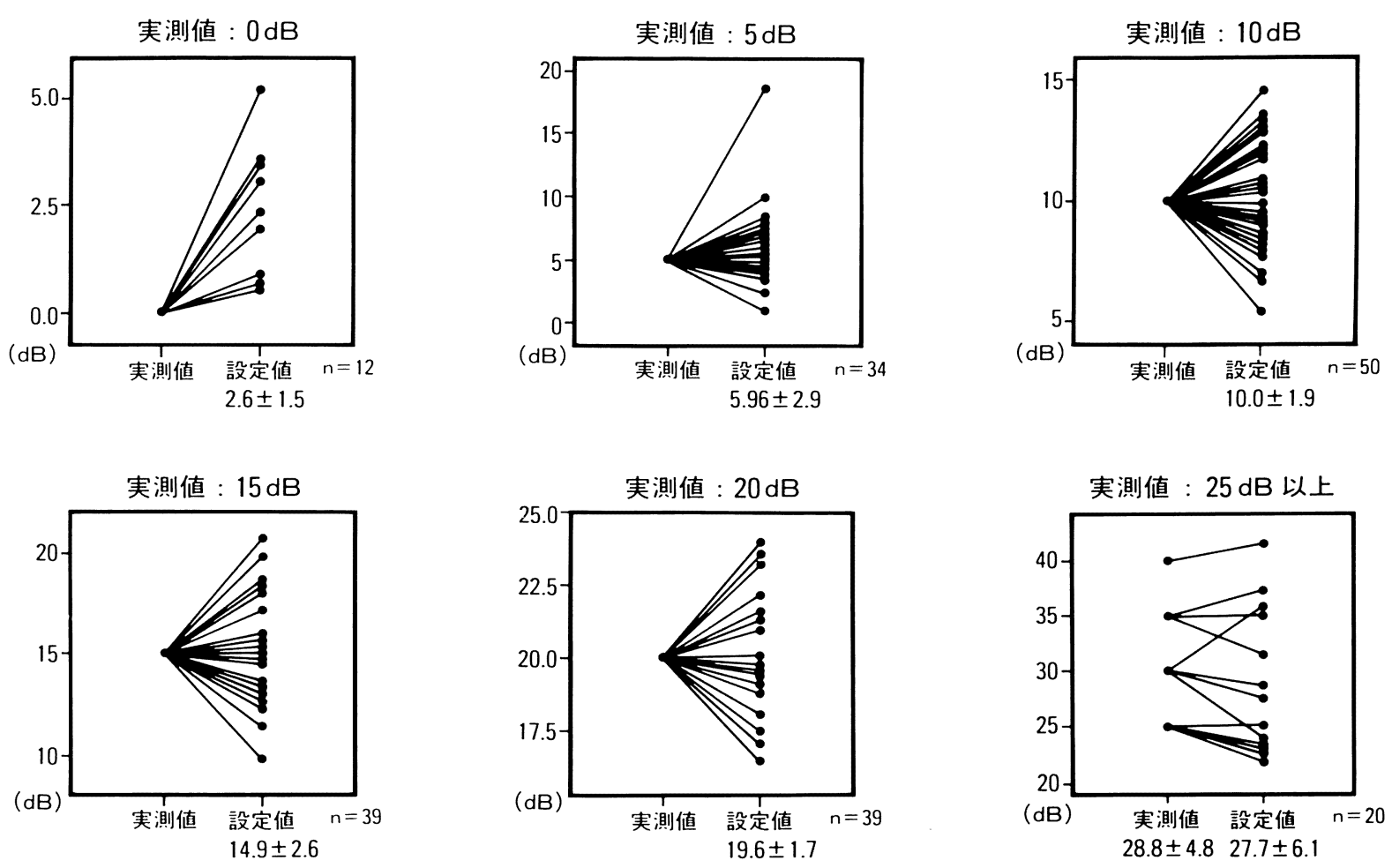

図17 図16を標準法のシミュレーションによる実測值 $\tilde{\mu}_{T}-\tilde{\mu}_{0}$ で分類した困 実測值 $0 \mathrm{~dB}$ 以外は，設定值 $\mu_{T}-\mu_{0}$ が上下に対称に分布しており幅は約 $\pm 5 \mathrm{~dB}$ である. $\tilde{\mu}_{T}-\tilde{\mu}_{0}$ と $\mu_{T}-\mu_{0}$ に有意差がないのが分かる. 
合は刺激の呈示法にかかわらず比較判断の法則 から大きくはずれることはないと考えられる.

但し耳鳴患者の場合 $\mu_{0}, \mu_{T}$ を直接知ることが できないので, $\mu_{0} \fallingdotseq \hat{\mu}_{0}, \mu_{T} \fallingdotseq \hat{\mu}_{T}$ と仮定して論を 進めた。一方耳鳴ラウドネス測定の場合は, シミュレーションの実測值 $\tilde{\mu}_{T}-\tilde{\mu}_{0}$ と設定值 $\mu_{T}-\mu_{0}$ の関係は特に有意差はみられなかった が，耳鳴患者の場合の標準法の実測值 $\tilde{\mu}_{T}-\tilde{\mu}_{0}$ 之恒常法の実測值 $\hat{\mu}_{T}-\hat{\mu}_{0}$ の関係は, 後者の方 が有意に大きな値になった。つまり耳鳴患者の 標準法による耳鳴ラウドネスの HL 值 $\tilde{\mu}_{T}$ が, シミュレーションによる $\tilde{\mu}_{T} に$ 比して，有意に 小さくなっていると考えられる.

恒常法は, 系列効果を相殺するように刺激系 列をランダムの順序で被検者に呈示する測定法

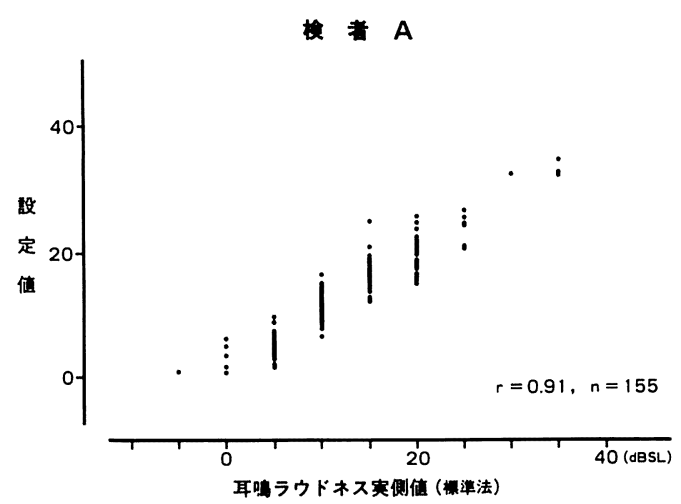

で反応母集団よりの任意抽出を行っている測定 法である. 最小可聴閾值測定では被検者の判断 は刺激の識別であるが，耳鳴ラウドネスの測定 では音刺激と実際の音でない耳鳴の弁別であり， 弁別は識別より強く系列効果の影響を受けると 考兄られる。耳鳴ラウドネスの場合いかに恒常 法による測定が有効であるかをらかがい知るこ とができる。

標準法による耳鳴ラウドネス測定に执いて被 検者に系列効果（尚早反応，慣れの誤差）や実 音に拈ける耳鳴のマスキングなどがなければ， 検者が変わってもあまり測定值にばらつきは生

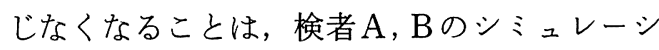
ョンの場合の設定值 $\mu_{T}-\mu_{0}$ と実測值 $\tilde{\mu}_{T}-\tilde{\mu}_{0}$ の 相関の強さ（図18に示すように相関係数 0.9 以

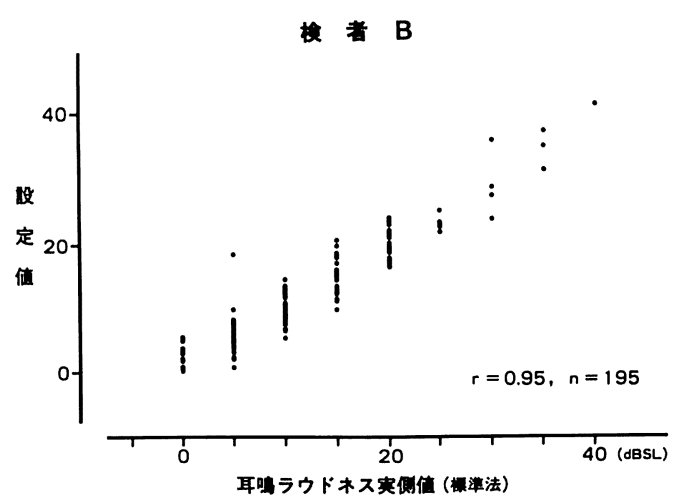

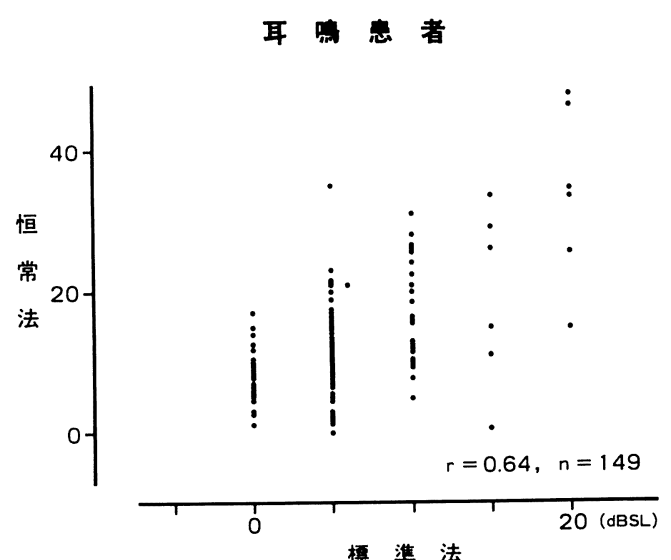

図18 上図は標準法のシミュレーションによる実測值 $\tilde{\mu}_{T}-\tilde{\mu}_{0}$ と設定值 $\mu_{T}-\mu_{0}$ の散布図.

下図は耳鳴患者の恒常法による実測值 $\hat{\mu}_{T}-\hat{\mu}_{0}$ と標準法による実測值 $\tilde{\mu}_{T}-\tilde{\mu}_{0}$ の散布図. 
上）で推定することができる，つまり耳鳴ラウ ドネス測定は，系列効果が最小可聴閾値測定と 比較して大きく現れるのではないかと考えられ る.

《実験 $4 》$

耳鳴ラウドネス值の評価における問題点に関 する実験

一感音性難聴耳の補充現象を中心に考察—

耳鳴ラウドネスをいくら正確に測定したとし てもそのデータには，様々な患者側の条件の違 いによる誤差を含んでいる，その中で大きな要 因の一つとして，測定耳の補充現象があげられ る. 耳鳴患者の中で感音性難聴を合併している ことが多く，評価する際に SL 值のみで比較す ることができない，特に高度難聴者の場合ダイ ナミックレンジが狭く測定が困難な上に数值が 非常に小さくなり同程度の耳鳴ラウドネスの聴 力正常者の場合の測定值とは桁の違うデータに なりかねない。

松平ら ${ }^{22)}$ は耳鳴ラウドネス評価の際に補充 現象の補正の必要性を強調し, 耳鳴の実効ラウ ドネスレベルの補正式（以下ラウドネス関数） を提唱した。耳鳴ラウドネス実測值に対して補 充現象の補正を行い，その有用性につき検討し た.

\section{1) 目 的}

耳鳴ラウドネス実測値に補充現象がどのよう にかかわっているか検討し，聴力正常耳の場合 ではどの程度のラウドネスになるかをラウドネ ス関数の換算により求め，その值を検討するこ とを目的とする。

\section{2）方 法}

1. 当科耳鳴外来に来院した後迷路難聴およ び伝音性難聴の患者を除く 149 耳で，耳鳴ラウ ドネス測定を標準法と恒常法で行い，聴力レベ ルとの関係をみる.

2 . 感音性難聴耳の 1 側耳鳴患者18名を, 患 側耳と対側耳を用いて耳鳴ラウドネス測定を行 い実効ラウドネスを求め，その関係扣よび実効 ラウドネスの患側評価と対側評価の差と精神測
定関数のパラメータとの関係をみる.

恒常法による耳鳴ラウドネス測定は前出した 方法と同様の方法で施行した。標準法は $5 \mathrm{~dB}$ ステップの上昇法で施行した。結果はすべて SL 值で示した.

3 ) 結 果

〔聴力レベルと耳鳴ラウドネス〕

図19に聴力レベル（最小可聴閾値）と耳鳴ラ ウドネスの関係について示す. 上段の左図は恒 常法による測定の関係を表している. 補充現象 により聴力レベルが大きくなるにつれて，耳鳴 ラウドネスの分布幅が圧縮されている様子が表 されている．相関係数はー0.25で弱い負の相関 を示している. 図20の感音性難聴のラウドネス 関数により実効ラウドネスに変換すると（但し a の值は松平の求めた 0.132 とした), 図19の上 段の右図のようになり分布幅は聴力レベルに関 係なくほぼ一定になり，相関係数が 0.60 と中等 度の正の相関になった，標準法の場合を図19の 下段左図に示す。恒常法のように明確な傾向は みられないが，聴力レベルと耳鳴ラウドネスの 関係は，やはり聴力レベルが大きくなるにつれ て耳鳴ラウドネス值の分布幅が圧縮されている. また相関係数はー0.29で弱いが負の相関を示す。 下段右図の実効ラウドネスの場合は分布幅が逆 に拡大傾向を示し相関係数は，0.28と弱い正の 相関を示した。標準法の場合, 耳鳴ラウドネス 值が $0 \mathrm{dBSL}$ である場合がみられ変換後も 0 $\mathrm{dBSL}$ になるのであまり強い相関にならなかっ た.

〔患側評価と対側評価〕

1 側耳鳴の患側評価と対側評価の関係を図 21 に示す．上段が恒常法による実測值の関係で, 下段が標準法の実測値の関係である．恒常法の 場合をみると耳鳴側に感音性難聴を合併してい る症例が多く， 3 例を除き $\mathrm{Y}=\mathrm{X}$ の軸より上方 に分布（患側評価の方が低值）しているが，ラ ウドネス関数で变換すると $\mathrm{Y}=\mathrm{X}$ 軸に対してほ ぼ対称に分布し，相関係数も0.41から0.83と飛 躍的に大さくなり， $\mathrm{Y}=\mathrm{X}$ に近い症例も多くな 
ったそそれに比し標準法の場合は，変換前の場 合も $\mathrm{Y}=\mathrm{X}$ の軸に対して上方に分布している症 例が恒常法の場合よりも少ない。また実効ラウ ドネスに変換しても $\mathrm{Y}=\mathrm{X}$ の軸に近づく症例も 少ない. 相関係数も 0.12 から0.30に变化しただ けである。

〔精神測定関数の各パラメータとの関係〕 恒常法による実効ラウドネスの患側と対側の 評価に执いても差がある症例がみられる。その 差と精神測定関数のパラメータとの関係につい てみてみた。図22に精神測定関数の標準偏差 $\hat{\sigma}_{T i}$ と耳鳴ラウドネスの患側評価と対側評価の 差の関係を示す．ほとんど無相関であった。
表 3 に評価耳の違いによる差と判断割合の正 規適合度との関係を求めたところ, 差が大きい ものが正規適合度が低いという傾向は特にみら れなかった。

図23に示す左右の聴カレベルの差と患側と対

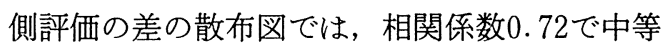
度の正の相関がみられた。

4) 小括

1. 耳鳴外来に訪れた患者149耳の耳鳴ラウ ドネスを測定したところ，聴力レベルが大きく なるに従って, 耳鳴ラウドネス值の最大値が小 さくなる傾向がみられた.

2. 18 名の 1 側耳鳴患者の耳鳴ラウドネスを
㯖カレヘルと耳响ラウドネス

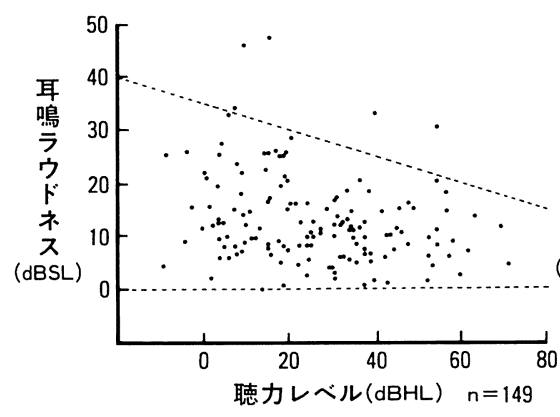

聴カレヘルと耳鳴ラウドネス

\section{㯖カレヘルとと实効ラウドネス}

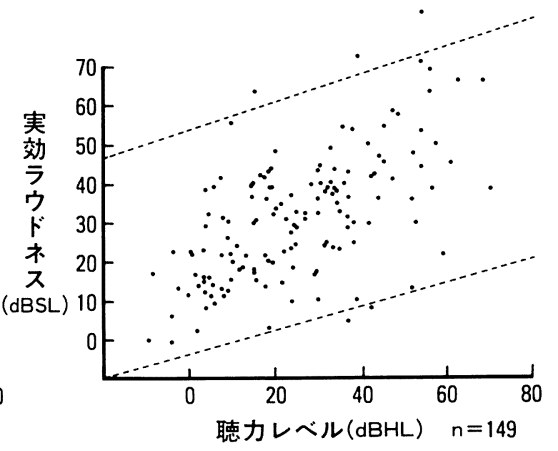

聴カレベルと実効ラウドネス
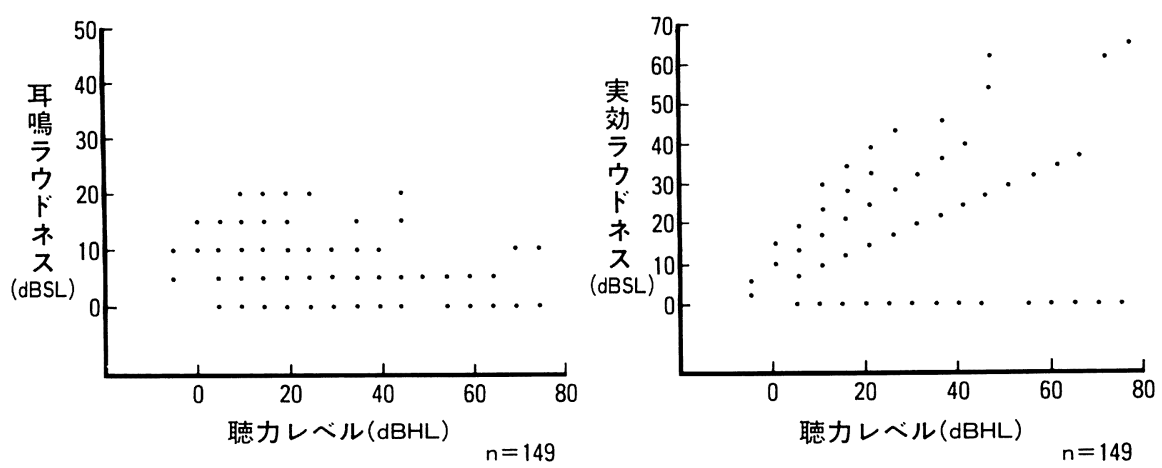

図19 聴力レベル（最小可聴間值）と耳鳴ラウドネス值および実効ラウドネス値との散布図 上段が恒常法により求めた值による関係で下段が標準法により求めた值による関係. 相関係数は左 上より $-0.25,0.60,-0.29,0.28$ となった。 
患側耳と対側耳で測定し，松平のラウドネス関 数により補充現象の補正を行った実効ラウドネ スを求めたところ以下の結果を得た。

(1)標準法の場合, 患側評価と対側評価の実効 ラウドネス值の相関係数が 0.30 であったが，恒 常法の場合は0.83であった.

(2)恒常法による実効ラウドネスで患側評価と 対側評価の差と精神測定関数のパラメータ $\hat{\sigma}_{T i}$

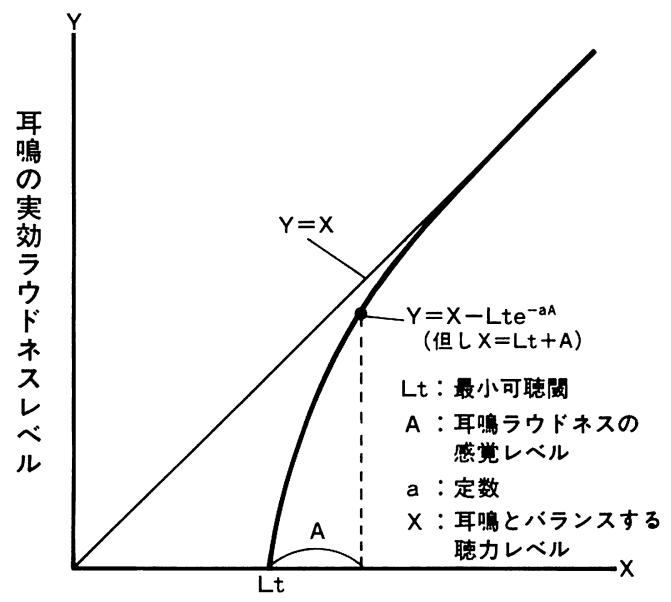

耳鳴とバランスする聴カレベル

図20 感音性難聴のラウドネス関数

(松平登志正，他 : 198722)より改変）
急側評価と対側評価(恒常法)

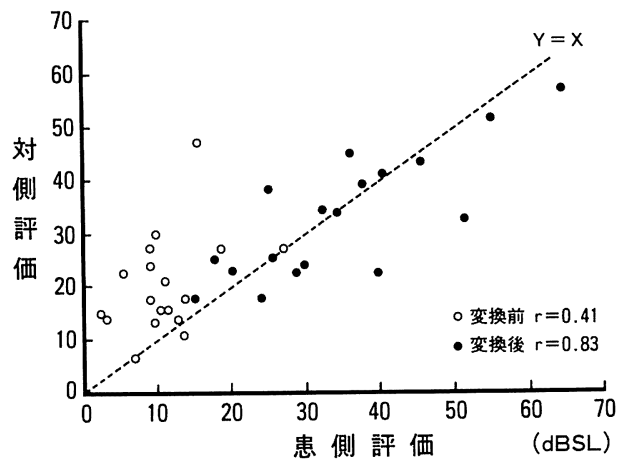

患側評価と対側評価(標準法)

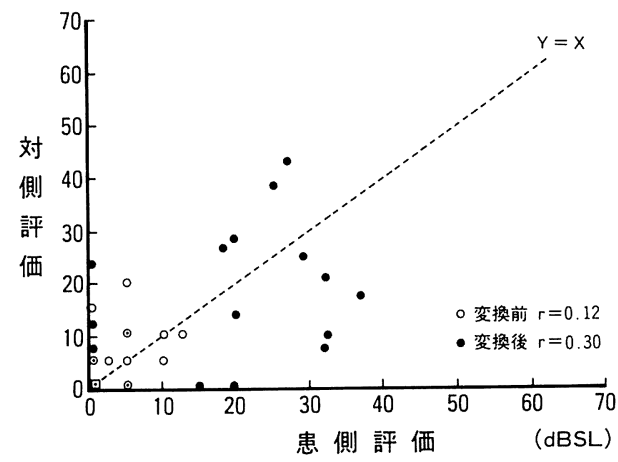

図21 耳鳴ラウドネス測定に护兴患側評価 と対側評価の関係を表す散布図

上段が恒常法で下段が標準法による関係を表 寸散布図.

表 3 恒常法による実効ラウドネスの患側評価と対側評価 の差と精神測定関数の正規適合度の関係 $\mathrm{p}$ が 1 に近い汪ど適合度が高い。

\begin{tabular}{r|cccccc}
\hline \hline & \multicolumn{5}{|c}{ 評価耳の違いによる誤差 (dB) } \\
\hline 適 合 度 & $0 \sim 3$ & $3 \sim 6$ & $6 \sim 9$ & $9 \sim 12$ & $12 \sim 15$ & 15 以上 \\
\hline \hline$p<.01$ & 0 & 1 & 0 & 1 & 0 & 1 \\
$.01 \leq p<.05$ & 1 & 0 & 0 & 0 & 0 & 0 \\
$.05 \leq p<.1$ & 1 & 0 & 0 & 0 & 1 & 0 \\
$.1 \leq p<.5$ & 5 & 2 & 1 & 0 & 0 & 1 \\
$.5 \leq p<.9$ & 1 & 0 & 2 & 0 & 0 & 0 \\
\hline
\end{tabular}


や正規適合度の関係をみたが，中等度以上の相 関はみられなかった。

(3)恒常法による実効ラウドネスで患側評価と 対側評価の差が大きい症例は，聴力差のある症 例に多く，測定誤差が大きな原因と考えられた。

(4)また，補充現象の程度に個体差があり，す べての症例の補充現象を一律のラウドネス関数 で補正するのは無理があるものと思われた。

5 ) 考 察

〔補充現象の補正]

ラウドネス・バランス検査を施行する際に, 測定耳に感音性難聴（内耳性難聴）があると補 充現象のため実測值が聴力正常耳で測定する場 合より小さくなることはよく知られている（山

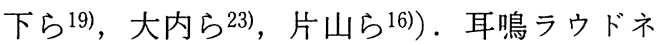
スは，難聴の無い耳で測定すべきであるという 意見もあるし，両側耳鳴の場合は，隣接する周 波数で難聴の無い周波数でバランス寸べきであ るといら意見もある。ところが実際，両側内耳 性難聴がある場合は，補充現象のある耳で耳鳴 ラウドネス測定を行わざるを得ない，そこで得 られた值は，そのままでは難聴のない症例の データと直接比較検討することはできない。そ の評価法について sone 表示を行ら方法, ラウ ドネス関数を用いる方法がある．補充現象の補 正法については, Lochner と Burger の関数 ${ }^{24}$ を用いて sone 表示をする方法や他に, Tyler と

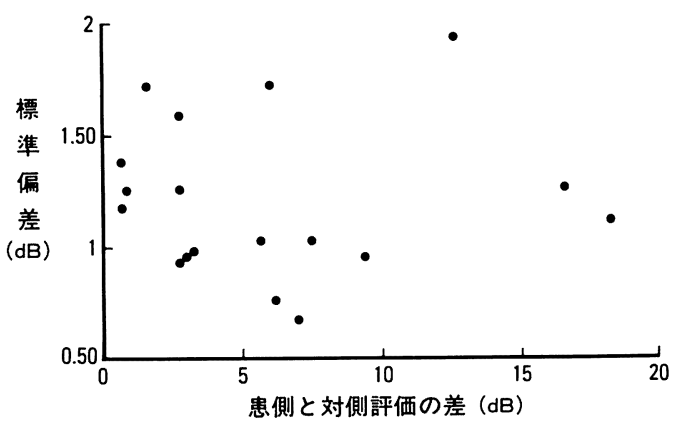

図22 精神測定関数の標準偏差 $\hat{\sigma}_{T i}$ と恒常法によ る耳鳴ラウドネスの患側評価と対側評価 の差の関係を表す散布図

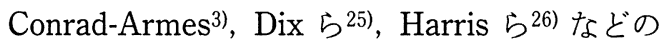
報告があり様々な関数にて表現している。 また Hallpike ら 27) は補充現象の様々なケースにつ いて論じている．30例のメニエール患者につい て ABLB 法を施行し典型的なラウドネス関数 について示している．場合によっては overrecruitment が生じ, $\mathrm{Y}=\mathrm{X}$ の軸をラウドネス 関数が越光てしまらことがあると述べている. 従って ABLB 法を施行した場合それがどのよ らな関数になるかについては，一律の関数で表 現するのは難しい面がある．本来ならば個々の 症例においてラウドネス関数を求め補充現象を 補正すべきなのであるが，ラウドネス関数を求 める方法が ABLB 法以外に確立されておらず, 両側感音性難聴の場合は測定ができず，また臨 㦿検査の面では測定操作が多様になり非実用的 である. そらいう理由で一律のラウドネス関数 で補正することにした。

松平のラウドネス関数は, over-recruitment には反応していないが， $\mathrm{Y}=\mathrm{X}$ の軸に漸近する 速度をa という一つの定数で表現できるといら 簡便さがある. sone 表示ではないので一般臨 床家にもなじみがあるので，この関数によって 耳鳴ラウドネス值の変換を行った．定数ａは松 平の求めた 0.132 用いた. 1 側耳鳴のラウド ネスを患側評価および対側評価を行い，補充現 象を上記の関数で補正し比較した際, 恒常法で

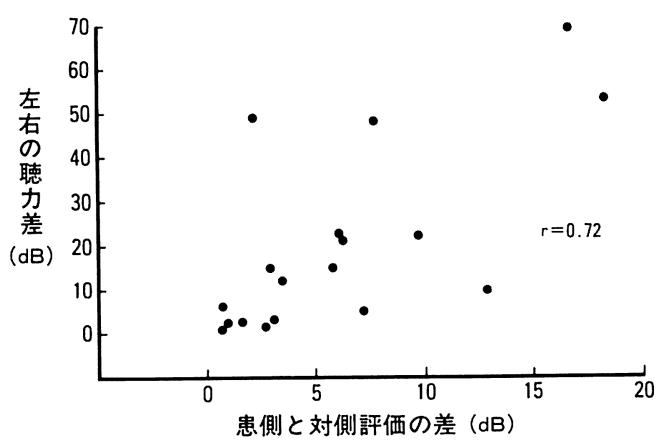

図23左右の聴力レベル（最小可聴閾值）の差と 実効ラウドネスの患側と対側評価の差の関 係を表す散布図 
はかなりの症例で両者が一致した。近似しない 症例も見られたので，測定誤差または左右の耳 のラウドネスの評価の違いによるものか, 補正 関数を一律にしたためか，を見るために恒常法 の各パラメータとの関係を見た. 左右の聴力差 の大きい程, 患側評価と対側評価の差が大きい といら正の相関がみられた。すなわち耳鳴ラウ ドネスの測定誤差による要因が大きいと思われ る. ラウドネス関数の定数 $\mathrm{a}=0.132$ がこの実 験の場合適当であるかどらか，またこの定数を 変更すれば実効ラウドネスの患側および対側評 価がほぼ一致するかどうかをみるために，今回 の実験で得られたデータより最小 2 乗法を用い て最適の定数を求めたところ， $\mathrm{a}=0.079$ にな った（図24）. 右図はラウドネス関数の $\mathrm{a}=$ 0.079 の場合で, 左罒は $\mathrm{a}=0.132$ の場合の実 効ラウドネスの患側評価と対側評価の関係であ る. 相関係数は 0.83 より0.85へとわずかの上昇 であり, いくつかの症例で $\mathrm{Y}=\mathrm{X}$ の軸に近づい たが離れたままの症例も見られた。その結果よ り定数 a が不適当と言うより, 補充現象の個体 差や実測値の測定誤差または over-recruitment, $\mathrm{Y}=\mathrm{X}$ の軸にいつまでも漸近しない不完全な補 充現象, 左右の耳の分離能の違いによるラウド
ネスの評価の差異によるものが考えられ, 補充 現象の補正については各症例ごとに考学る必要 がある.しかし臨床検査として症例ごとにラウ ドネス関数を求めるわけにはいかないので, 平 均的な補充現象の補正を行ってみた. 実験の結 果では, 一律のラウドネス関数がすべての症例 の補充現象の補正を網羅するものではないが， それでもその信頼区間を明示しておけば実用に 耐え得ると考えられる.

149耳のデータでは聴力レベルと実効ラウド ネスが正の相関になったが，本当は無相関にな るべきであったかどらかは検討の余地があると 考光られる。

\section{III. 全編の考察}

今回, 恒常法による耳鳴ラウドネス法を用い て, 数々の実験を通じてその精度の優秀性を示 してきた. 恒常法による聴覚心理学的測定法が どのような理論に基づいて精密な測定ができる ように考えられているかを, 方法論として以下 に述べた。また，今回どのようにコンピュータ による恒常法の効率化を行ったかについても記 述した。
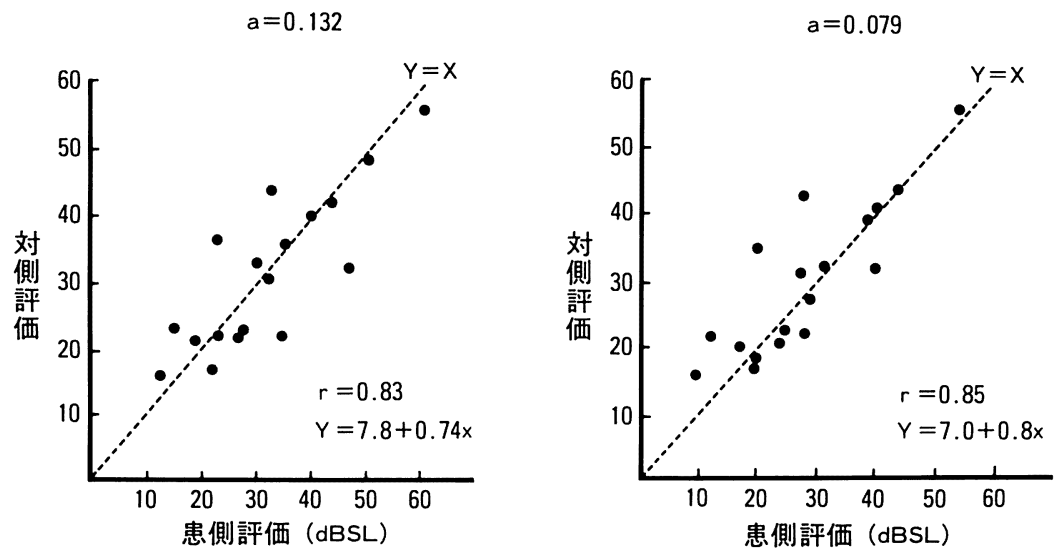

図24 ラウドネス関数 $Y=X-L_{T} e^{-\mathrm{a} A}$ の定数 $\mathrm{a}$ の違いによる実効ラウドネスの患側評 価と対側評価の関係の違い

左図が $\mathrm{a}=0.132$ (松平の原法) の場合で, 右図が $\mathrm{a}=0.079$ （当実験で求めた值）の場合. 
1. 恒常法の方法論

〔比較判断の法則〕

恒常法は，数種類の刺激よりなる刺激系列を あらかじめ刺激発見法（極限法など）により推 定した所定值がその範囲に含まれるように設定 し，各刺激をランダムの順序で被検者に提示す る. 被検者には各水準の刺激に対して「有，無」 (識別 : identification)，あるいは「大，小」(弁 別： discrimination) ${ }^{28)}$ など 2 肢強制選択 (2 AFC) をさせて各水準に対し判断比率を求め, それをもとに精神測定関数 (psychometric function）を推定しその平均值 $\mu$ を求めることを目 的とする方法である．精神測定関数とは，弁別 過程の確率的モデルより求められるもので29), 1 刺激の識別と 2 刺激の并別の場合にわけられ る.

(1) 1 刺激の識別の場合を図25に示す.ここで $S_{i}$ を与えた場合反応は, 心理学的連続体上で, $N\left(R_{i}, \sigma_{i}{ }^{2}\right)$ で表される正規分布に従うと仮定す る.

反応 $R_{i}$ に対し境界 $\mu_{0}$ が存在し， $S_{i}$ が境界よ り大きいと判断する確率，つまり刺激が識別さ れる確率 $p_{y}$ は,

$$
p_{y}=\frac{1}{\sqrt{2 \pi} \sigma_{i}} \int_{\mu_{0}}^{\infty} \exp \left\{-\frac{1}{2}\left(\frac{R_{i}-\bar{R}_{i}}{\sigma_{i}}\right)^{2}\right\} d R_{i} \cdots \text { (1) }
$$

で表される。

そこで $\mu_{0}$ を固定值と仮定して $S_{i}$ の関数に変 換すると，

$$
p_{y}=\frac{1}{\sqrt{2 \pi} \sigma_{i}} \int_{-\infty}^{S_{i}} \exp \left\{-\frac{1}{2}\left(\frac{S-\mu_{0}}{\sigma_{i}}\right)^{2}\right\} d S \cdots
$$

となる。

そこで $Z_{i}=\frac{S_{i}-\mu_{0}}{\sigma_{i}}$ と変数変換を行うと，

$p_{y}=\frac{1}{\sqrt{2 \pi}} \int_{-\infty}^{Z_{i}} e^{-\frac{Z^{2}}{2}} d Z=\phi\left(Z_{i}\right)$

$Z=0$ を与えるときの $S_{i}$ が絶対閾であり，つ まり $S_{i}=\mu_{0}$ ということになる.

(2) 2 刺激の弁別の場合について述べるが，こ のモデルは Thurstone ${ }^{3031)}$ の比較判断の法則と 呼ばれている，例えば耳鳴刺激 $S_{T}$, 検査音刺 激を $S_{i}$ とすると，その反応は図26亿示すよう に $N\left(\bar{R}_{T}, \sigma_{T}{ }^{2}\right), N\left(\bar{R}_{i}, \sigma_{i}{ }^{2}\right)$ と正規分布し，その 差も $N\left(\bar{R}_{T i}, \sigma_{T i}{ }^{2}\right)$ と正規分布する（但し $\sigma_{T i}=$ $\sqrt{\sigma_{T}{ }^{2}+\sigma_{i}{ }^{2}-2 r_{T i} \sigma_{T} \sigma_{i}}: r_{T i}$ は $R_{T}$ と $R_{i}$ の相関係 数).

耳鳴の方が大きいと判断する確率 $p_{T>i}$ は次 式で表される.

$$
p_{T>i}=\frac{1}{\sqrt{2 \pi} \sigma_{i}} \int_{0}^{\infty} \exp \left\{-\frac{1}{2}\left(\frac{R_{T i}-\bar{R}_{T i}}{\sigma_{T i}}\right)^{2}\right\} d R_{T i}
$$

$S_{T}$ および $\bar{R}_{T}$ は固定された值で定数でありま た， $S_{i}=\bar{R}_{i}, \mu_{T}=\bar{R}_{T}$ とすると(4)式は

$$
p_{T<i}=\frac{1}{\sqrt{2 \pi} \sigma_{T i}} \int_{-\infty}^{S_{i}} \exp \left\{-\frac{1}{2}\left(\frac{S-\mu_{T}}{\sigma_{T i}}\right)^{2}\right\} d S
$$

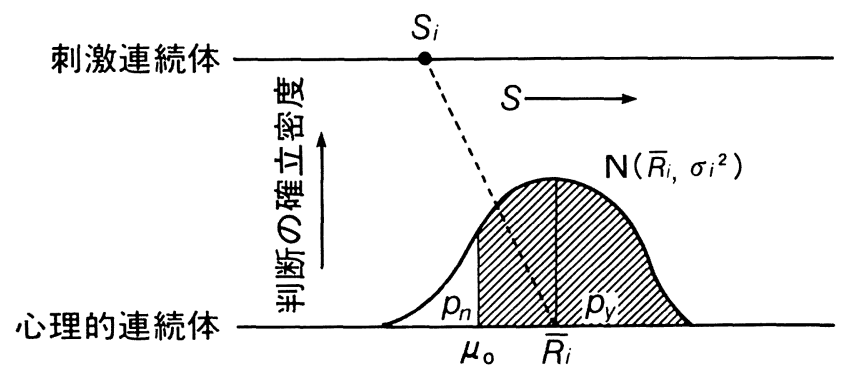

図25 刺激 $S_{i}$ をとえたときの刺激を「有」と判断する確率の識別過程の確率的モデル 
このように $S_{i}$ の関数で表すことができる.

ここで $Z_{i}=\frac{S_{i}-\mu_{T}}{\sigma_{T i}}$ と変数変換を行うと,

$p_{T<i}=\frac{1}{\sqrt{2 \pi}} \int_{-\infty}^{Z_{i}} e^{-\frac{Z^{2}}{2}} d Z=\phi\left(Z_{i}\right)$

(3)式と同じ形になり $Z$ と $S$ は線形関係であ る. $p_{y}=p_{n}=0.5$ ( $p_{n}$ : 刺激を識別しない確率 $)$ を与える $S_{i}$ が絶対閾 (absolute limen) というこ とになり $\mu_{0}$ と表し， $p_{T>i}=p_{T<i}=0.5$ を与える $S_{i}$ が耳鳴と主観的等価值 (PSE : point of subjective equality) $\bar{R}_{T i}$ に相当し $\mu_{T}$ と表した. い ずれの場合も $Z=0$ のときの $S_{i}$ を求めればよい ことになる。 また $S_{i}$ と $Z_{i}$ は線形関係であるの で $S_{i}$ を与えたとき最小可聴閾值を測定する場 合は「刺激が識別できる」，または耳鳴ラウド
ネス測定の場合「刺激の方が耳鳴より大きいと 弁別される」ときの誤差を含む判断確率 $p^{\prime}{ }_{i}$ を 求め, $Z_{i}=\phi^{-1}\left(p_{i}^{\prime}\right)$ 上り $Z_{i}$ を求める. $Z$ と $S$ は 線形関係であるから，

$$
\mathrm{S}=a+b \mathrm{Z}
$$

といら 1 次回帰式で近似することができる.

最小 2 乗法でそれぞれの係数を求めると回帰係 数は, $b=\frac{\sum S_{i} Z_{i}-n \bar{S}_{i} \bar{Z}_{i}}{\Sigma S_{i}{ }^{2}-n\left(\bar{S}_{i}\right)^{2}}$ で求められ,

(7)式より $a=\bar{Z}_{i}-b \bar{S}_{i}$ より $a$ を求める.

$Z=0$ のときの $S$ の值が絶対閾または主観的 等価值で目的の值であり， $-\frac{a}{b}$ で求められ普 通 $\mu$ で表される。 また $Z$ に抢ける 1 の变化に 対応する $S$ の变化分が精神測定関数の標準偏

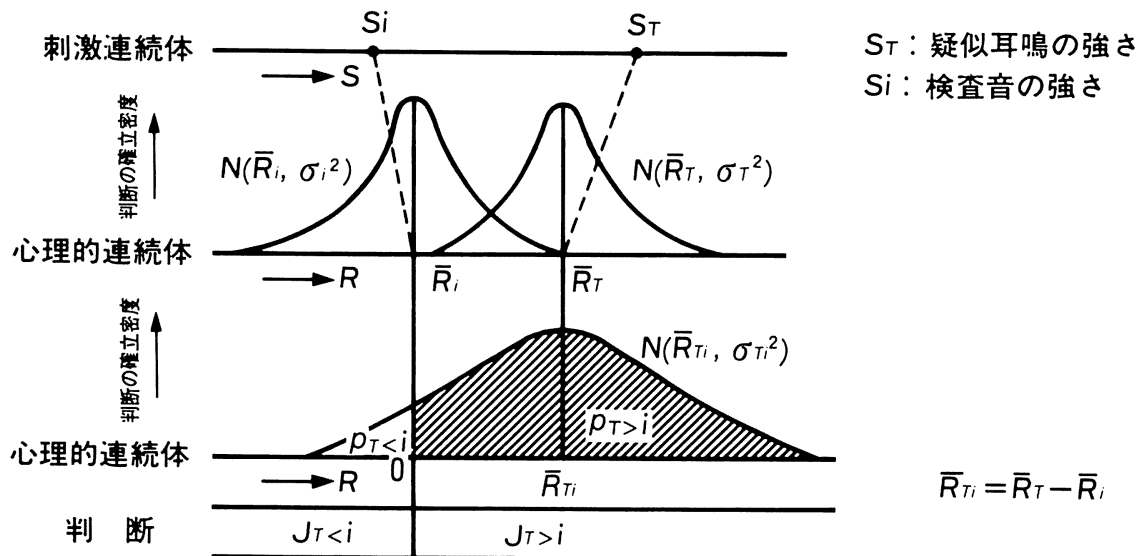

精神測定関数 $: p_{T>i}=\frac{1}{\sqrt{2 \pi} \sigma_{T_{i}}} \int_{0}^{\infty} \exp \left\{-\frac{\left(R_{T i}-\bar{R}_{T_{i}}\right)^{2}}{2 \sigma T_{T_{i}}{ }^{2}}\right\} d R_{T_{i}}$

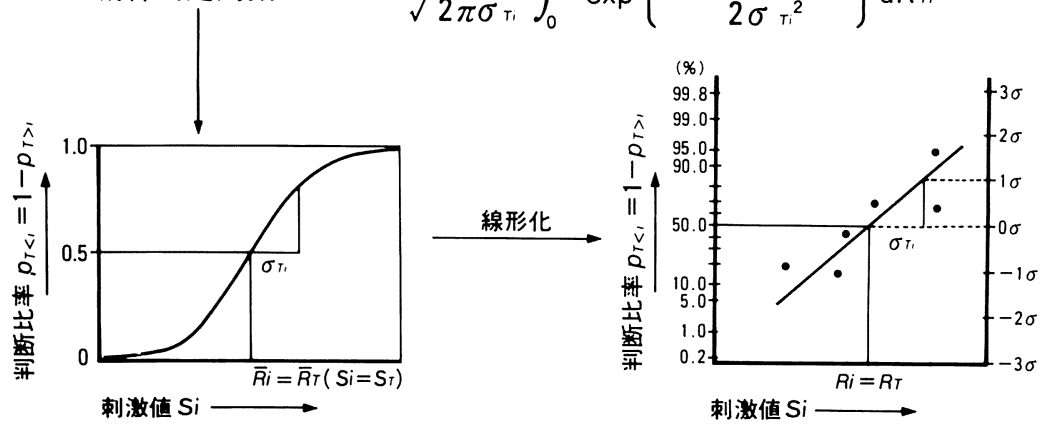

図26 Thurstone の比較判断の法則に従った耳鳴と検査刺激との并別過程の確率的モデル 

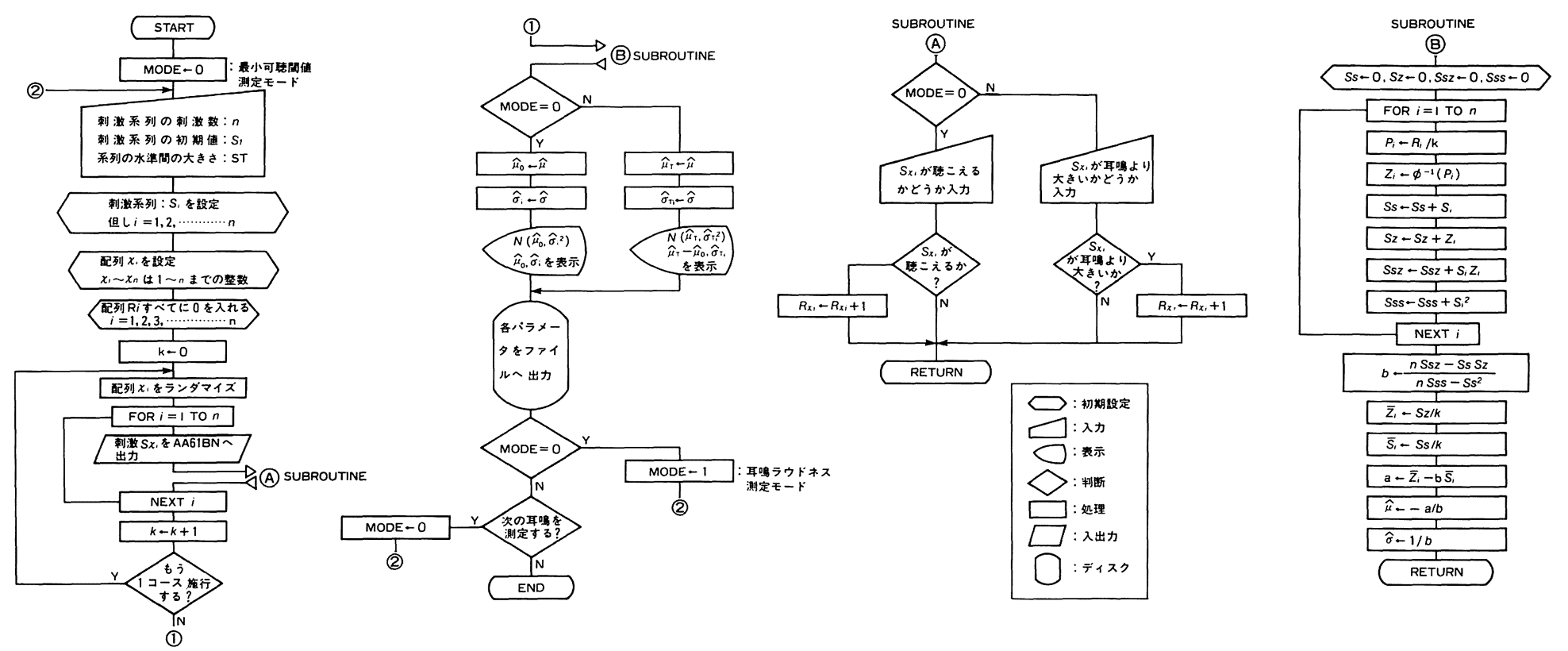

図27佰常法による耳鳴ラウドネス值 $\hat{\mu}_{T}-\hat{\mu}_{0} \mathrm{dBSL}$ をコンピュータで求めるためのフローチャート SUBROUTINE A では被検者の判断の入力, SUBROUTINE B では正規補間法の最小 2 乗法を行っている. 
差 $\sigma$ であるから $\sigma=\frac{1}{b}$ で求められる.

恒常法は，刺激系列 $S_{i}(i=1 ， 2 ， 3, \cdots \cdots, n)$ をランダムの順序で各水準あたり多数回呈示す ることにより判断比率 $p$ を求めている.これは $N\left(\mu, \sigma^{2}\right)$ の反応母集団よりの任意抽出を行らこ とによって系列効果（尚早反応，慣れの誤差） を回避して扣り，また判断比率 0.5 という精神 測定関数の最も安定する部分を実測值とする事 により精度が上がるのである。

以上に示した直線回帰によって精神測定関数 を求める方法が, 正規補間法の最小 2 乗法と呼 ばれている. 判断比率 $p$ より $Z$ の值を求める が, $p$ が 0.5 付近の $Z$ の変化率より, $p$ が 0 ま たは 1 付近の $Z$ の変化率が著しく大きくなる ため, $p$ の值に応じて加重をつける方法 MüllerUrban 法がある. またさらに詳細に $\mu$ を推定

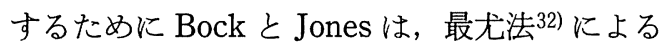
推定法を提唱したが，反復呈示数が少ないとあ まり意味がないとされている.今回の実験では 刺激系列の各水準の刺激の呈示回数を等しくし たので，正規補間法の最小 2 乗法を採用した.

[恒常法の検査手続き]

恒常法の実際の検査手続きについて述べる. まず $S_{i}(i=1,2,3, \cdots \cdots, n)$ という $n$ 個の通常 は等間隔の刺激系列を， $\mu$ がその中にくるよう に刺激発見法（極限法など）などで設定する. かかる刺激をランダムの順序で 1 水準当たり多 数回呈示し，その刺激に対して被検者はあらか じめ定められた反応「有, 無」(識別 : identification), あるいは「大, 小」(弁別 : discrimination）の判断を 2 肢強制選択する. 次に刺 激系列の各水準に対する判断比率 $p_{i}(i=$ $1,2,3, \cdots \cdots, n)$ を記録する.

計算手続きは，上記の刺激系列 $S_{i}$ とその判 断比率 $p_{i}$ より III-1 の項目で述べた方法で, 精 神測定関数のパラメータ $\mu, \sigma$ の推定值である $\hat{\mu}, \hat{\sigma}$ を求める. 被検者の反応が識別の場合 $\mu$ が絶対閾 (absolute limen) であり, 弁別の場合 が主観的等価值 (PSE : point of subjective equality) である.

以上が一般的な恒常法の測定手続きであるが， 今回最小可聴閾值および耳鳴ラウドネス測定に 使用した刺激系列は $1 \mathrm{~dB}$ 間隔の 10 刺激であり, ランダムの順序で 1 水準あたり10回呈示した. 通常の恒常法と較べて呈示回数が少ないのは, 未経験な被検者の聴覚疲労を招かないよう配慮 したためである. 1 水準あたり10回呈示, 20 回 呈示, 50 回呈示の 3 種類の方法で耳鳴ラウドネ ス測定の予備実験を施行したが， $\hat{\mu}_{T}$ の值にほ とんど影響を与えなかった。

[検査法の効率化]

以上示したように恒常法の検査および計算手 続きをみると，極限法などの直接的な測定法と 比較すると検査手技が非常に繁雑で効率が悪く， 検者の操作ミス，計算ミスなどを誘い易い。刺 激系列のランダムの順序の呈示法扣よび呈示回 数の多さや正規補間法の最小 2 乗法の計算の繁 雑さがその主な原因である.手動操作および手 計算で施行していては，とても臨床検査として は利用できない，そこで刺激の呈示と計算手続 きをコンピュータで行わせることを考案した。 そのフローチャートは図27に示す. 以上の手続 きを自動化することにより恒常法による耳鳴 ウドネス測定が20４0分で施行することが可能 となった。

\section{2. 耳鳴検査法の現状と将来への展望}

《実験 $1 》 て ゙ は$ 恒常法による耳鳴ラウドネス 測定の精度を擬似耳鳴を使用して標準法と比較 した．恒常法の精度が標準法より優れていると

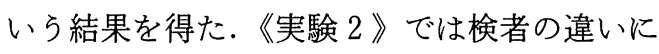
よる耳鳴ラウドネス測定のばらつきを恒常法と 標準法で比較し, 恒常法の方がばらつきが小さ

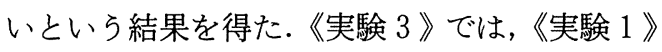

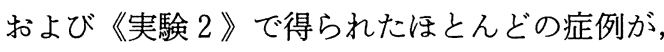
$\hat{\mu}_{T}-\hat{\mu}_{0}>\tilde{\mu}_{T}-\tilde{\mu_{0}}$ であったという結果の理由を 調ベるため標準法のコンピュータ・シミュレー ションを行った. ラウドネス・バランスを行ら ときの系列効果がおそらく原因であるらしいと いら結果を得た。《実験 4 》では, 耳鳴ラウド 
ネス值が測定する側に感音性難聴があるとき, 補充現象により小さくなることが知られている. 補充現象を補正して正常聴力耳での実測値に修 正できるかどらかを検討した．問題は残るもの の, 恒常法の場合は耳鳴の絶対的なラウドネス の指標として使うことができるという結果を得 た.

以上のように実験をすすめたところ，耳鳴ラ ウドネスを恒常法によって測定することによっ て精度の向上をはかることができた。また精度 の向上によって実効ラウドネスなどの耳鳴の新 しいパラメータを検討することができる．とこ ろが精度の向上のための方法には, 問題点も新 たにつきまとらことになる．以下に示すように 耳鳴の評価法には恒常法に限らず多くの問題を 抱えている. 恒常法は精度の向上の為の解決法 の 1 つの手段にすぎないことを考虑しながら， さらに検討を重ね耳鳴評価法を改善していく必 要がある。

〔耳鳴の評価法〕

耳鳴の評価法は，大きくわけて主観的評価， 客観的評価に分けられる.

a ）主観的評価

(1)擬声語による耳鳴の音色およびピッチの 評価 ${ }^{33)} \sim 36$ )

(2)主観的耳鳴ラウドネス評価

(3)耳鳴の気になり方の評価

(4)耳鳴の持続時間

b ) 客観的評価

(1)ピッチ・マッチ検査 37 ～40)

(2)ラウドネス・バランス検査 20141$) \sim 44)$

(3)耳鳴遮蔽検査 (tinnitogram) ${ }^{5) 45) ~ 48)}$

c) 生理学的評価

(1)ABR などによる生理学的評価 ${ }^{49)}$

以上に分類されるが $\mathrm{c}$-11)現在は汪とんど 確立されて括らず，やはり耳鳴検査は主観的評 価および聴覚心理学的検査に頼らざるを得ない のが現状である．前述したように耳鳴ラウドネ ス值は $10 \mathrm{dBSL}$ 以下が大部分を占めているが, 人によりほとんど気にならないものから，気に
なって仕事も手につかないものまであるという 事実がある．朝隈ら 5051$)$ によると，心身医学的 見地からみると心理的因子が耳鳴に対する過度 の囚われを起こしていると考えられている。そ の心理的因子は，性格，音に対する敏感さ，疾 患に対する不安などがあり，主観的評価に少な からず影響を与えており, 真の耳鳴ラウドネス に強い相関をしているとは思えない，客観的評 価法にも心理的因子が関与していることは否め ないが，朝隈らの述べていると抢り治療法を確 立し, 現在行われている様々の治療法の再評価 のためにも客観的評価方法を完成することが早 急な課題である.

[恒常法の効率化の検討]

耳鳴ラウドネスの客観的評価法をできるだけ 聴覚心理学的に正確に測定するために, 恒常法 を使用し今回の実験でそれを実証したのである が，コンピュータの使用によりかなり効率化を 行ったが実際の臨床上ルーチンで行われる検査 としてはまだ不十分なところがある，その対策 法としては,

1 ) 恒常法より効率のよい精神物理学的測定 法, 例えば適応法 (adaptive method) ${ }^{52}$ により 測定する.

2 ) 刺激系列の刺激水準数を所定值がそのな かにくるよらに工夫しながら減少させる．

3 ）被検者の応答を検者がいちいち入力する のではなく直接インターフェイスを使用して被 検者に入力させる.

4) 被検者の応答の適否をコンピュータに判 断させる.

5 ）検査要領をコンピュータに音声インター フェイスを使って被検者に説明させる.

などが考えられるが，1）の適応法とは，あら かじめ設定されたいくつかの刺激レベルで行わ れる測定法（固定法）に対し，各施行で呈示さ れる刺激レベルが，それまでの応答結果の全部 または一部の履歴によって逐次決められるとい ら実験手続きの総称である. 数々の方法論が報 告されて扣り代表的なものに， 
(1)PEST 法 (parameter estimation by sequential testing) ${ }^{53) 54)}$

(2)最尤法 (maximum likelihood sequential procedure) $)^{55)}$, 但し恒常法の最尤法 (maximum likelihood solution) とは異なる

(3)混合適応法 (hybrid adaptive procedure) ${ }^{56}$

(4)QUEST 法 (bayesian adaptive psychometric method $)^{57)}$

などがあり，いずれも実施にはコンピュータを 必要とし, 効率や精度についてはそれぞれ特徵 があり最尤法, 混合適応法, QUEST 法などは かなり恒常法に近いが，系列効果は否定できな い，適応法である程度所定值を絞り込み，狭い 範囲の刺激系列を設定し恒常法を施行すること も考光られる。

2 ）の方法として, 最尤法または, MüllerUrban ${ }^{58)}$ 法は判断比率の荷重を行らことによっ て刺激系列の各水準の刺激の提示回数は同じで ある必要がないので, 所定值が限定されるに従 って刺激系列の水準数を減少させる（判断比率 が 0 と 1 になる刺激の呈示を割愛する）ことが できるので効率化の方法として考案中である.

3) はコンピュータ・インターフェイスの開 発によって比較的容易に実現できる。

4 ）は精神測定関数の標準偏差や正規適合度 などのパラメータにより, 被検者の応答の確か さを判断し，検者に知らせたり刺激の呈示回数 を増やすなどして実現できる。

しかし，5）は被検者の了解の判断をいかに するかなどの問題を抱えて拉り実現は困難であ る.

以上の問題が列挙されるがコンピュータを利 用したことにより，検査法の開発の自由度はか なり向上59) しているので，効率がよく，かつ 高精度の耳鳴ラウドネス測定法を完成させるこ とが近い将来できるものと思われる.

\section{N 。おわりに}

以上我々は，コンピュータを用いた恒常法に よる耳鳴ラウドネス測定法の有用性や問題点に ついて述べてきた。高精度の耳鳴ラウドネス測
定が手軽にできることにより，実効ラウドネス の実用化が進み主観的評価法との関係も明確に することができる．また治療効果判定も明確に できるなど, 耳鳴研究の発展の一端を担らこと になる，ところが，恒常法が測定精度に执いて 優れていることは認められてはいるが，その施 行は容易でないために実際の臨床では行われる ことは少なかった．そのために他の聴覚心理学 的方法による測定が行われ, 精度上の行き詰ま りを見せているのが現状である。

コンピュータが出現したときに聴覚心理学者 たちの中には，恒常法の面倒な手続きをそれに 行わせ，精度の高い測定を容易にすることを考 えたに違いない，実際それらの研究報告もある． しかし，初期の頃は聴覚実験にコンピュータを 利用するにも，音刺激の発生に $\mathrm{D} / \mathrm{A}$ 变換など のハードの専門的知識を要し，ソフト開発も機 械語などの複雑な言語知識や面倒なプログラミ ングの労力を要した.

最近はめざましい技術の発達によりコンピ ュータもパーソナルな時代になり, 高性能機種 が安価にもたらされるようになった．また周辺 機器の充実や誰でも分かりやすいプログラミン グ言語の開発により著者のような專門知識のな い者でも比較的容易に聴覚心理実験を行らこと ができるよらになり，コンピュータによるコン トロールが可能な聴力検査機器も出現した. こ のことは, 高度な聴覚心理学研究を行ら上で, 誠に望ましい環境であり，いずれ専門知識のな い者でも高精度な測定が容易にできる機器が次 次に開発されることであろら，そうなるまでに はさらなる試行錯誤，データの収集が必要であ るが，著者もその一端を担らべく努力を重ねて いく所存である.

尚, 本論文の要旨は, 1989年 7 月第 9 回，1990年 7 月第 10 回, 1991 年 7 月第 11 回日本聴覚医学会耳鳴 研究会, 1990年 6 月日本耳鼻咽喉科学会大阪地方連 合会第233回例会, 1990年11月第35回日本聴覚医学会 総会に扣いて発表した。 
謝 辞

稿を終えるにあたり，御指導，御校閲を賜りまし た近畿大学医学部耳鼻咽喉科学教室太田文彦教授, 助言を賜りました同教室村田清高助教授をはじめ医 局員の諸先生に，またラウドネス関数に関して御教 示賜りました金沢医科大学耳鼻咽喉科学教室松平登 志正先生に謝意を表します.

\section{参考文献}

1) Fowler EP : Head noises in normal and in disordered ears. Arch Otolaryngol 39 : 498 503, 1944.

2) 耳鳴研究会編 : 標準耳鳴検査法1984. 第 4 回耳 鳴研究会記録集. $1 \sim 9$ 頁, 東京, 1985.

3) Tyler RS and Conrad-Armes D : The determination of tinnitus loudness considering the effects of recruitment. J Speech Hear Res $26: 59 \sim 72,1983$.

4）田中良久 : 極限法. 心理学的測定法. 34 45頁, 東大出版会, 東京, 1988 .

5）大内利昭, 田中康夫 : 耳鳴ラウドネスとマスキ ングレベルの相関性. Audiol Jpn $30: 812 〜 816$, 1987.

6) Hood JD: Studies in auditory fatigue and adaptation. Acta Otolaryngol supple $92: 1 \sim 57$, 1950.

7) Jeager JF : Auditory adaptation. J Acoust Soc Am 29 : 357 363, 1957.

8）高木興一, 山本剛夫 : 恒常法, 調整法および量 推定法による短音のラウドネスの測定結果. 日 衛誌 $38: 530,1983$.

9) Guilford JP:恒常法による閾値の標準誤差（秋 重義治訳). 精神測定法. 162 163頁, 培風館, 東京, 1959 .

10）太田文彦，今泉 敏 : PAST 法 ; 耳鳴の新しい 聴覚心理的検査法. 耳鼻 $30: 1000 \sim 1004,1984$.

11）吉江信夫 : 情報理論による耳鳴の測定の試み. 日耳鼻 $65 ： 425 \sim 431,1961$.

12）松平登志正, 山下公一：耳鳴の Residual inhibition に関与する因子.Audiol Jpn 26 : 123〜128, 1983.

13）黒川泰資 : Residual Inhibition (RI) とマスカー 療法の関係. 耳鼻臨床 補25:21～28, 1988.

14）大山健二，富岡幸子：耳鳴患者に打ける Residual Inhibition の観察. Audiol Jpn 26 :
129 132, 1983.

15）神崎 仁，大内利昭：耳鳴バランス法の再現性 および信頼性に関する検討.耳鼻 $30 ： 1037$ 1046, 1984.

16）片山雄二, 久住 武, 岡本途也, 他 : 耳鳴の臨 床的検討. 耳鼻 30 : 996 971, 1984.

17）杉本和彦, 白石孝之: 大阪大学耳鳴外来の紹介. 耳鼻臨床 補41：8～18, 1991.

18）卜部信行：耳鳴の臨床統計的検討. 耳鼻臨床 $78: 1731 \sim 1745,1985$.

19）山下公一, 松平登志正 : 耳鳴の臨床的研究一統 計的観察と耳鳴検査の問題点一. 耳鼻 $30: 958$ $\sim 965,1984$.

20) Goodwin PE and Johnson RM : The loudness of tinnitus. Acta Otolaryngol $90: 353 \sim 359$, 1980.

21) Vernon J : The loudness (?) of tinnitus. Hear Speech Act $44: 17 \sim 19,1976$.

22）松平登志正, 山下公一 : 耳鳴の大きさの評価法 について，電子情報通信学会 補87: 53〜 58, 1987.

23）大内利昭, 神崎 仁：耳鳴ラウドネス・バラン ス検査の再検討. Audiol Jpn $33: 76 \sim 83,1990$.

24) Lochner JPA and Burger JF : Form of the loudness function in the presence of masking noise. J Acoust Soc Am 33 : 1705 1707, 1961 .

25) Dix MR : Loudness recruitment and its measurement with especial reference to the loudness discomfort level test and its value in diagnosis. Ann Otol Rhinol Laryngol 77 : 1131 $\sim 1151,1968$.

26) Harris JD and Haines HL : Loudness perception for pure-tones and for speech. Arch Otolaryngol $55: 107 \sim 133,1952$.

27) Hallpike CS and Hood JD : Observations upon the loudness recruitment phenomenon with especial reference to the differential diagnosis of disorder. Proc R Soc Med 41: 516 526, 1948.

28）寺西立年：音響心理学に打ける基本的な諸問題. 聴覚心理研究会資料 資料番号84-1-1：1～19, 1984.

29）境 久雄, 中山 剛：弁別過程の確率的モデル. 聴覚之音響心理. 242 244頁，コロナ社，東京， 
1984.

30) Thurstone LL : A law of comparative judgment. Psychol Rev 34 : 273 286, 1927.

31）田中良久: 比較判断の法則. 心理学的測定法. 159 161頁, 東大出版会, 東京, 1988 .

32）田中良久 : 最尤法. 心理学的測定法. 63〜 68頁, 東大出版会, 東京, 1988 .

33）福與和正, 曽田豊二 : 耳鳴の音色的表現に関す る実験的検討. 耳鼻 $30: 972 \sim 977,1984$.

34）福與和正, 森 俊文, 曾田豊二, 他 : 耳鳴の音 色表現に関する臨床的検討. 耳鼻 30 : 978 984, 1984.

35）曽田豊二：耳鳴の音色の客観的評価方法. 耳鼻 $30: 985 \sim 992,1984$.

36）大内利昭, 岡田行弘 : 耳鳴の自覚的表現に関す る再検討 一自発的擬声語と耳鳴周波数および 純音・雑音性との関係一. Audiol Jpn 33:48 $\sim 55,1990$.

37) Ellis D and Reid J : The diagnostic value of tinnitus pitch. J Laryngol Otol 82 : 1039 1043, 1968.

38) Tylor RS and Conrad-Armes D : Tinnitus pitch; a comparison of three measurement methods. Br J Audiol 17 : 101 107, 1983.

39）小田 恂：自覚的耳鳴に対するピッチマッチ検 查. 耳鼾 $30: 1005 \sim 1007,1984$.

40）宮崎 巨, 山下公一, 松平登志正 : 耳鳴のピッ チマッチ法の精度に関する検討.耳鼻 30 : 1008 1013, 1984.

41) Penner MJ : Equal-loudness contours using subjective tinnitus as the standard. J Speech Hear Res 27 : 274 279, 1984.

42）大内利昭 : 耳鳴検査法. 耳喉頭頸 $61: 11 ; 983$ $\sim 987,1989$.

43）大内利昭, 神崎 ヒ：バランス法による耳鳴の 評価. Audiol Jpn 26 : 105 111, 1983.

44）大内利昭, 神崎 壬: バランステストによる耳 鳴の評価. Audiol Jpn 25 : 545〜546, 1982.

45) Mitchell $\mathrm{C}:$ The masking of tinnitus with pure tones. Audiology 22 : 73 87, 1983.
46）大内利昭, 田中康夫 : バンドノイズ及び純音に よる耳鳴マスキングレベル. Audiol Jpn 32 : 118 124, 1989.

47) 神崎 仁：耳鳴遮蔽検査と Residual Inhibition の測定. 耳鼻 $30: 1026 \sim 1030,1984$.

48）村井和夫, 立木 孝: 耳鳴遮蔽検査法の検討. Audiol Jpn 28 : 547 548, 1985.

49) Shulman A : ABR and tinnitus-an overview. J Laryngol Otol 97 supple $9: 170 \sim 177,1983$.

50）朝隈真一郎, 曽田豊二 : 耳鳴患者への心身医学 的アプローチ. 耳鼻 $30: 1063 \sim 1069,1984$.

51）朝隈真一郎：耳鳴と心身医学. 耳喉頭頸 61 : 997〜 1001, 1989.

52）津村尚志：最近の聴覚心理実験における新しい 測定法. 日本音響学会誌 $40: 45 \sim 51,1984$.

53) Findlay JM : Estimates on probability functions; a more virulent PEST. Percept Psychophys $23: 181 \sim 185,1978$.

54) Taylor MM and Creelman CD : PEST ; Efficient estimates on probability functions. J Acoust Soc Am 41 : 782 787, 1967.

55) Pentland A : Maximum likelihood estimation; the best PEST. Percept Psychophys $28: 377$ $\sim 379,1980$.

56) Hall JL : Hybrid adaptive procedure for estimation of psychometric functions. J Acoust Soc Am 69 : 1763 1769, 1981.

57) Watson AB and Pelli DG : QUEST; a Bayesian adaptive psychometric method. Percept Psychophys $33: 113 \sim 120,1983$.

58）田中良久 : Müller-Urban 法. 心理学的測定法. 61～63頁，東大出版会，東京，1988.

59）津村尚志，石川浩資：マイクロコンピュータを 用いた音響心理実験システム。日本音響学会誌 論文集 $179: 219 \sim 220,1987$.

$\left(\begin{array}{l}\text { 原稿受付 : 平成 } 4 \text { 年 } 3 \text { 月 } 16 \text { 日 } \\ \text { 原稿採択 : 平成 } 4 \text { 年 } 4 \text { 月 } 28 \text { 日 } \\ \text { 別刷請求先: : 原田昌彦 } \\ \text { †593 堺市鳳中町3-62-30 } \\ \text { 原田耳鼾咽喉科 }\end{array}\right)$

